2. To: (Receiving Organization)

Distribution

5. Proj./Prog./Dept./Div.:

W-44I/Spent Nuclear Fuel

8. Originator Remarks:

Initial release issued for configuration control.

3. From: (originating organization) Cold Vacuum Drying Facility

6. Design Authority/ Design Agent/Cog. Engr.:

J. J. Irwin

11. Receiver Remarks: 11A. Design Baseline Document? [] Yes [X] No
4. Related EDT No.:

$n / a$

7. Purchase Order No.:

$n / a$

9. Equip./Component No.:

$\mathrm{n} / \mathrm{a}$

10. System/Bldg./Facility:

CVD Facility

12. Major Assm. Dwg. No.:

$\mathrm{n} / \mathrm{a}$

13. Permit/Permit Application No.: $n / a$

14. Required Response Date:

$n / a$

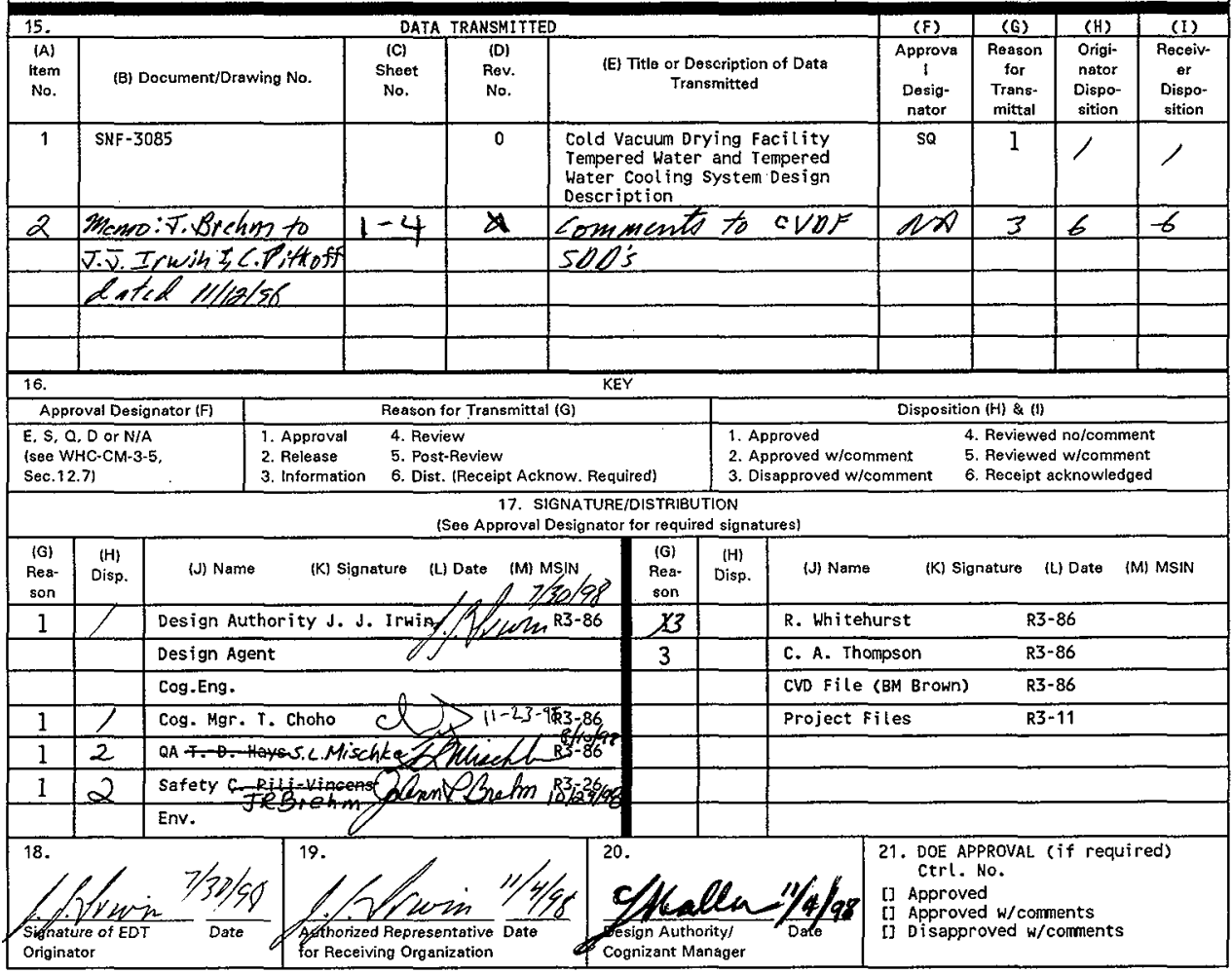

BD-7400-172-2(05/96) GEF097 


\section{SPENT NUCLEAR FUEL PROJECT COLD VACUUM DRYING FACILITY TEMPERED WATER AND TEMPERED WATER COOLING SYSTEM DESIGN DESCRIPTION}

\section{J. J. Irwin}

Numatec Hanford Corporation, Richland, WA 99352

U.S. Department of Energy Contract DE-AC06-96RL13200

EDT/ECN: 625189

Org Cade: 8C453

B\&R Code: $39 E W 70400$
UC: 721

Charge Code: LH302

Total Pages: 63

Key Words: Cold Vacuum Drying, System Design Descriptions

Abstract: This document provides the System Design Description (SDD) for the Cold Vacuum Drying Facility (CVDF) Tempered Water (TW) and

Tempered Water Cooling (TWC) System. The SDD was developed in conjunction with HNF-SD-SNF-SAR-002, Safety Analysis Report for the Cold Vacuum Drying Facility, Phase 2, Supporting Installation of Processing Systems (Garvin 1998), The HNF-SD-SNF-DRD-002, 1998, Cold Vacuum Drying Facility Design Requirements, and the CVDF Design Summary Report. The SDD contains general descriptions of the TW and TWC equipment, the system functions, requirements and interfaces. The SDD provides references for design and fabrication details, operation sequences and maintenance. This SDD has been developed for the SNFP Operations Organization and shall be updated, expanded, and revised in accordance with future design, construction and startup phases of the CVDF until the CVDF final ORR is approved.

TRADEMARK DISCLAIMER. Reference herein to any specific commercial product, process, or service by trade name, trademark, manufacturer, or otherwise, does not necessarily constitute or imply its endorsement, recommendation, or favoring by the United States Government or any agency thereof or its contractors or subcontractors.

Printed in the United States of America. To obtain copies of this document, contact: Document Control Services, P.O. Box 950, Mailstop H6-08, Richland WA 99352, Phone (509) 372-2420; Fax (509) 376-4989.
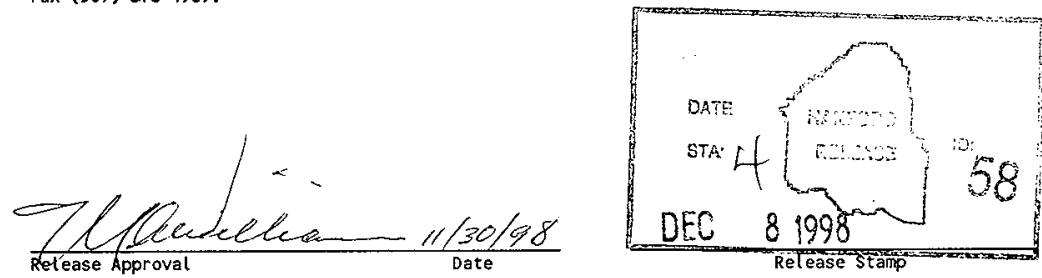


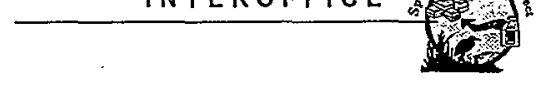

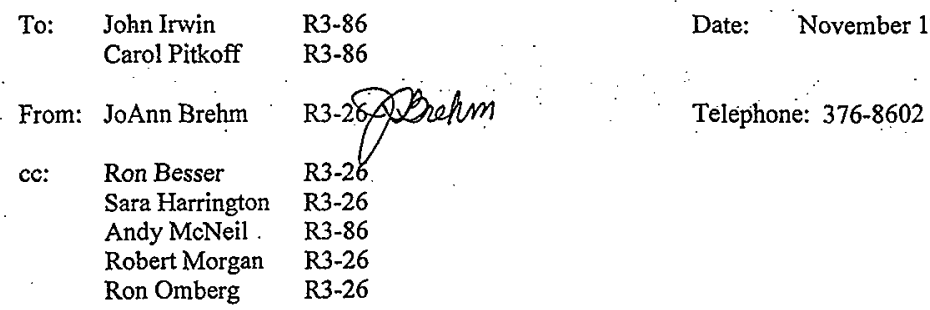

Subject: COMMENTS ON COLD VACUUM DRYING FACILITY SYSTEM DESIGN DESCRIPTION

SNF-3062 (EDT 625179)

SNF-3063 (EDT 625180)

SNE-3067 (EDT 625181)

SNF-3068 (EDT 625182)

SNF-3075 (EDT 625183)

SNF-3077 (EDT 625184)

SNF-3081 (EDT 625185)

SNF-3082 (EDT 625186)

SNF-3083 (EDT 625187)

SNF-3084 (EDT 625188)

SNF-3085 (EDT 625189)

SNF-3086 (EDT 625190)

SNF-3087 (EDT 625191)
CVDF Vacuum and Purge System Design Description

CVDF Residual Gas Monitoring System Design description

CVDF General Service Helium System Design Description

CVDF Safety Class Helium System Design Description

CVDF Safety Electrical System Design Description

CVDF Fire Protection System Design Description

CVDF Heating, Venting, and Air Conditioning System Design

Description

CVDF Process Water Conditioning System Design Description

CVDF Conditioned Water Shipping System Design Description

CVDF Contaminated Water Sampling and Analysis System

Design Description

CVDF Tempered Water and Tempered Water Cooling System

Design Description

CVDF Chilled Water System Design Description

CVDF Vacuum and Purge System Chilled Water System Design Description
SNF-XXXX
(EDT XXXXXX)
SNF-XXXX (EDT XXXXXX)
SNF-XXXX (EDT XXXXXX)
CVDF Structural Systems Description
CVDF Crane Description
SNF-XXXX
(EDT XXXXXX)
CVDF De-Ionized Water System
CVDF Potable Water System
SNF-XXXX: (EDT XXXXXX)
SNF-XXXX (EDT XXXXXX)
CVDF Condensate Collection Description
CVDF Effluent System
SNF-XXXX
(EDT XXXXXX)
CVDF Compressed and Instrument Air System

Twenty SDDs were transmitted to the SAR Safety organization for review and approval. Specific sections of two SDDs (SNF-3062, Vacuum and Purge System and SNF-3068, Safety Class Helium System) were reviewed for their ability to provide the system information required for preparing the CVDF FSAR. Section 3.0, "System Function," of the SDDs was of most interest to the SAR Safety organization for preparing the final. SAR. It is noted that many comments previously submitted have been incorporated. It is also noted that some information is neither identified in the SDDs nor in any other design baseline document. 


\section{COMMENTS}

\section{SNE-3061 and SNE-3068}

Section 3.0 (SNF-306! and SNF-3068) was reviewed and it was noted that even though the SAR and SEL were referenced in this section, the information as noted in the revision number of these documents (as referenced in Section 9.3) was not documented accurately in the SDD. This section of the SDDs appears not to have been changed since the February 11, 1998 revision we reviewed. Between then and the latest SAR and the SEL as referenced in the SDDs, the systems have changed and this change is not reflected in the SDDs. All required safety class and/or safety significant equipment is not identified in the SDDs.

\section{SNF-3062 AND SNF-3068}

The Section 3.2 "SAFETY FUNCTIONS," is a combination of several things. It appears to try to identify information from the SAR accident analysis but falls short of providing complete and accurate information. It also appears to identify some other safety functions (from the DRD?). Since the term "safety function" is used as a very specific term in SARs, suggest that this section is kept pure and talks to just the "safety functions" identified in the SAR, Chapter 4.0. If the system is not a safety class or safety significant SSC then this section can state that in accordance with HNF-SD-SNF-SAR-002, there are no safety functions for this system. Perhaps all these other safety functions that are identified in the SDD but not in the SAR can be placed in a sub section listed, for example, "Non-SAR Safety Functions." (found a close example in the way Sections 3.2 and 3.3 in SNF-3075 were prepared).

Specific safety functions for each system (if required) is identified in Section 4.0 of the SAR. (The following descriptions also include the requirements of DOE-STD-3009-94.)

Section 4.3.5.1, "Safety Function," (of the SAR) states the safety function of the VPS (also applies to SNF-3068 but SAR Section 4.3.2):

1. Provides the safety-class function of isolation of the MCO from the VPS upon SCIC system actuation of the VPS isolation valves during the thermal nunaway reaction.

2. Initiates the safety-class process instrument signals to the SCIC system to initiate SCIC activation that is credited for the thermal runaway reaction.

3. Performs the above functions to prevent or mitigate the safety-significant consequences of the gaseous release, internal hydrogen explosion and the external hydrogen explosion.

4. Provides additional "water isolation" of the MCO from potential water ingress sources during and after the proof-of-dryness demonstration (use of redundant safety-class valves).

5. Safety-class pressure instruments are also utilized during the pressure hold tests.

Section 4.3.5.2, "System Description," provides a description of each safety-class component. For the VPS this includes valves, connectors, flexible piping, hard piping, instruments, pressure transmitters, pressure indicators, and a differential pressure indicator/transmitter.

Section 4.3.5.3, "Functional Requirements," identifies the requirements that are specifically needed to fulfill the safety functions of the VPS safety-class components.

Section 4.3.5.4, "System Evaluation," this section provides performance criteria imposed on the components so they can meet the functional requirements and thereby satisfy their safety function. Performance criteria characterize the specific operational responses and capabilities necessary to meet functional requirements. An evaluation is performed to see if the capabilities of the components meet the performance criteria. 
The same comment above can be made for the other SDDs.

The SDDs need to be consistent with the SAR, i.e., the systems in Section 3.2 of the SDDs need to be identical to that Chapter 4.0 (corresponding subsection) of the SAR. The SDDs also need to provide some detailed description of the SSCs to be used in Section 4.3.5.2 of the SAR. MII additon the SDOS ned to identify how the systems (or components) can met the requirements identified in Section 4353 of the SAR so that they can perform their "safety function as

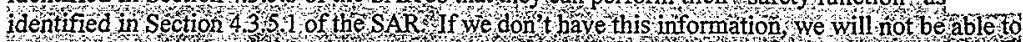
conclude in the SAR that We have the appropr ate SSCS that Will nakethe CVDF a safe facility

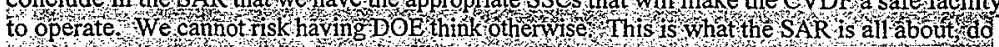

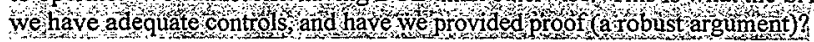

\section{SNF-3062, Section 2.1.3}

Change sentence to read: "... The water vapor removed from the MCO is ..." (change "form" to "from.")

\section{SNF-3062, Section 3.2 .4}

Identify all performance category items for the VPS and provide a reference. The second sentence in the paragraph, "All process water conditioning ..." has nothing to do with the VPS system. Change this to the VPS. Provide a reference to the study or section of the SDD that evaluates the VPS SSCs and their ability to perform their safety function. (The SDD will not be able to provide a reference because no evaluation has been performed and/or documented yet. The evaluation is the responsibility of the SDD in Section 3.0 for not just NPH, but for the SAR design basis accidents. See previous comments on Section 3.0 of the SDD above.)

\section{SNF-3062, Section 8.1}

The title of the section is "Potential System and Component Failure," however the contents do not comply with what appears to be the identified content matter of this section. First, the vacuum and purge system that this SDD was prepared for is not identified in the radioactive liquid release accident. Also, the SAR does not do a systematic review of the VPS failure. The SAR assumes systems are non-existent (or do not provide mitigation) so that an unmitigated dose can be calculated and then appropriate SSCs are identified to bring the dose to below guidelines for onsite and offsite doses. The SAR identifies that these SSCs must meet certain criteria and how the SSCs are built to meet the criteria to ensure that they can perform their intended safety function. But, the SAR does not identify system or component failure analysis. None of the other SSDs have a section on "System Design Analysis." Either delete this section from SNF3062 or revise Section 8.1 to reference a correct failure analysis study.

\section{SNF-3075}

Section in this SDD does not always follow the same format as most of the other SDDs (SNF3062, SNF-3063, etc.) Should the format be consistent, if not, why?

Description in Section 1.0, "Introduction," is more detailed than in Section 2.1 "General Description." Should this be the reverse, if not, why?

It is an interesting way of dividing Safety Function (Section 3.2) and Nonsafety Function (Section 3.3). Section 3.2 should reference the SAR (as long as the information is correctly summarized 
from the SAR). Section 3.3 could address all the other non-SAR items that the SDD may have to address.

\section{SNF-3081}

There is more system description (Section 1.1.2) and sometimes the exact description (Sections 1.1.3 and 1.1.5) in Section 1.0 as in Section 2.1 of the SDD. A summary system description. should be in Section 1.0 with the more detailed description in Section 2.0.

Section 3.1.2 (and following sections) should specifically list by consistent nomenclature the system components that are safety class or safety significant as identified in the SAR. Identify these here since they need to be evaluated in this section (see comment on Section 3.0 for SNF3062).

\section{Crane SDD}

There is very little description here, as a matter of fact you can find more description on the crane in the SAR than in the SDD. Add enough description so that this SDD is a stand-alone document.

\section{GLOBAL COMMENTS FOR ALL SDDS}

1. In general, Section 2.1 of all the SDDs has less descriptive information than the SAR (i.e., SCHe - SAR Section 2.5.4.2, VPS - SAR Section 2.5.3, etc.). SNF-3081 is better.

2. In general, Section 3.2.4 of all the SDDs has the same problem as noted in the comment above on SNF-3062. Provide a reference to the study or section of the SDD that evaluates the system SSCs and their ability to perform their safety function. (The SDD will not be able to provide a reference because no evaluation has been performed and/or documented yet. The evaluation is the responsibility of the SDD in Section 3.0 for not just NPH, but for the SAR design basis accidents. See previous comments on Section 3.0 of SNF-3062 above.)

3. Section 4.12.2 - As it currently reads it is not a true statement. Change the paragraph to read:

\subsubsection{Decontamination and Decommissioning}

A conceptual decontamination and decommissioning plan for the CVDF, as identified in the guidelines of DOE-STD-3009-94, Preparation Guide for U.S. Department of Energy Nonreactor Nuclear Facility Safety Analysis Reports, is scheduled for the final SAR.

HNF-SD-SNE-SAR-002 (Rev 4/4a) states that this is scheduled for the FSAR. It is not in the Phase 2 SAR that is referenced in the SDDs. 
SYSTEMS 47-1 and $47-2$

\author{
Numatec Hanford Corporation \\ Richland, Washington
}

COGEMA Engineering Corporation

Richland, Washington 
SNF-3085 REV 0

This page intentionally left blank. 


\section{CONTENTS}

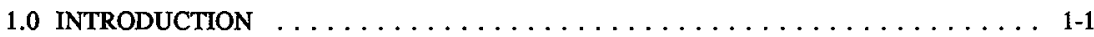

1.1 SUMMARY DESCRIPTION OF EQUIPMENT $\ldots \ldots \ldots \ldots \ldots \ldots \ldots \ldots$ 1-1

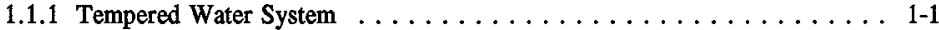

1.1.2 Tempered Water Cooling System $\ldots \ldots \ldots \ldots \ldots \ldots \ldots \ldots \ldots \ldots \ldots \ldots \ldots, 1-2$

1.2 ROLE OF SYSTEM IN PROCESS $\ldots \ldots \ldots \ldots \ldots \ldots \ldots \ldots \ldots \ldots \ldots$

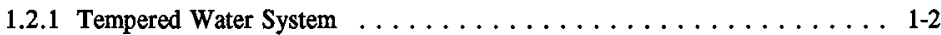

1.2.2 Tempered Water Cooling System $\ldots \ldots \ldots \ldots \ldots \ldots \ldots \ldots \ldots$ 1-2

1.3 TECHNICAL RESPONSIBILITY OF SYSTEM DESIGN DESCRIPTION . . . . . 1-2

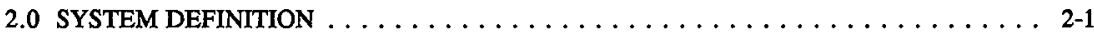

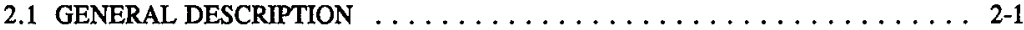

2.1.1 Tempered Water System $\ldots \ldots \ldots \ldots \ldots \ldots \ldots \ldots \ldots \ldots . \ldots \ldots .1$

2.1.2 Tempered Water Cooling System $\ldots \ldots \ldots \ldots \ldots \ldots \ldots \ldots .2-1$

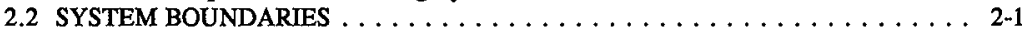

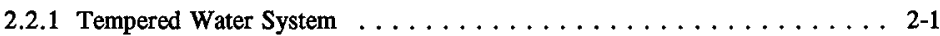

2.2.2 Tempered Water Cooling System $\ldots \ldots \ldots \ldots \ldots \ldots \ldots \ldots \ldots .2-1$

2.3 SYSTEM INTERFACES $\ldots \ldots \ldots \ldots \ldots \ldots \ldots \ldots \ldots \ldots \ldots \ldots \ldots \ldots \ldots \ldots .2-2$

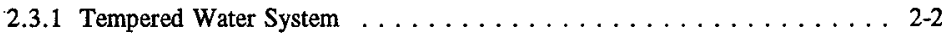

2.3.2 Tempered Water Cooling System $\ldots \ldots \ldots \ldots \ldots \ldots \ldots \ldots \ldots \ldots \ldots \ldots$

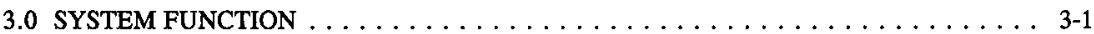

3.1 SYSTEM CLASSIFICATION $\ldots \ldots \ldots \ldots \ldots \ldots \ldots \ldots \ldots \ldots \ldots$ 3-1

3.1.1 Tempered Water System $\ldots \ldots \ldots \ldots \ldots \ldots \ldots \ldots \ldots \ldots \ldots \ldots \ldots .1$

3.1.2 Tempered Water Cooling System $\ldots \ldots \ldots \ldots \ldots \ldots \ldots \ldots \ldots .3-1$

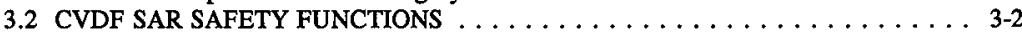

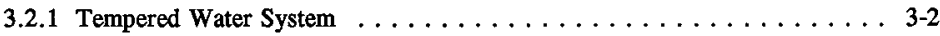

3.2.2 Tempered Water Cooling System $\ldots \ldots \ldots \ldots \ldots \ldots \ldots \ldots \ldots .3-2$

3.3 Non-SAR SAFETY FUNCTIONS $\ldots \ldots \ldots \ldots \ldots \ldots \ldots \ldots \ldots \ldots \ldots .3^{3-2}$

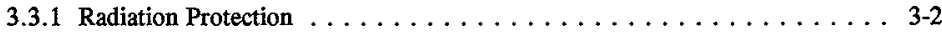

3.3.2 Natural Phenomena Hazard Mitigation (Seismic) $\ldots \ldots \ldots \ldots \ldots . . .3$

3.3.3 Worker Safety Hazards Protection $\ldots \ldots \ldots \ldots \ldots \ldots \ldots \ldots$ 3-3

3.4 ENVIRONMENTAL FUNCTIONS $\ldots \ldots \ldots \ldots \ldots \ldots \ldots \ldots \ldots \ldots$ 3-4

3.4 .1 Tempered Water System $\ldots \ldots \ldots \ldots \ldots \ldots \ldots \ldots \ldots \ldots \ldots \ldots \ldots$

3.4.2 Tempered Water Cooling System $\ldots \ldots \ldots \ldots \ldots \ldots \ldots \ldots$ 3-4

4.0 SYSTEM REQUIREMENTS . . . . . . . . . . . . . . . . . . . 4 4-1

4.1 OPERATIONAL AND FUNCTIONAL REQUIREMENTS AND BASIS FOR REQUIREMENTS $\ldots \ldots \ldots \ldots \ldots \ldots \ldots \ldots \ldots \ldots \ldots \ldots \ldots \ldots \ldots \ldots \ldots \ldots \ldots, 1$

4.1.1 Tempered Water System $\ldots \ldots \ldots \ldots \ldots \ldots \ldots \ldots \ldots \ldots$ 4-1

4.1.2 Tempered Water Cooling System . . . . . . . . .

4.2 CIVIL AND STRUCTURAL REQUIREMENTS $\ldots \ldots \ldots \ldots \ldots \ldots$. $\ldots \ldots$

4.2.1 Tempered Water System . . . . . . . . . . . . . . 4-5

4.2.2 Tempered Water Cooling System $\ldots \ldots \ldots \ldots \ldots \ldots \ldots \ldots$. 4.6

4.3 MECHANICAL REQUIREMENTS $\ldots \ldots \ldots \ldots \ldots \ldots \ldots \ldots \ldots \ldots$. $\ldots \ldots$

4.4 MATERIALS REQUIREMENTS $\ldots \ldots \ldots \ldots \ldots \ldots \ldots \ldots \ldots \ldots$ 4-6

4.4.1 Tempered Water System $\ldots \ldots \ldots \ldots \ldots \ldots \ldots \ldots \ldots \ldots \ldots \ldots \ldots$

4.4.2 Tempered Water Cooling System . . . . . . . . . . . 4 4 


\section{CONTENTS (Continued)}

4.5 INSTRUMENTATION AND CONTROLS $\ldots \ldots \ldots \ldots \ldots \ldots \ldots$. . . . . . . . . .

4.5.1 Tempered Water System $\ldots \ldots \ldots \ldots \ldots \ldots \ldots \ldots \ldots \ldots .4 .9 \ldots$

4.6 RELIABILITY REQUIREMENTS $\ldots \ldots \ldots \ldots \ldots \ldots \ldots \ldots \ldots \ldots \ldots$ 4-10

4.6.1 Tempered Water System $\ldots \ldots \ldots \ldots \ldots \ldots \ldots \ldots \ldots .4 .4 .10$

4.7 ENVIRONMENTAL REQUIREMENTS $\ldots \ldots \ldots \ldots \ldots \ldots \ldots \ldots \ldots$. . . . . . . . . .

4.7.1 Tempered Water System $\ldots \ldots \ldots \ldots \ldots \ldots \ldots \ldots \ldots \ldots$ 4 410

4.7.2 Tempered Water Cooling System $\ldots \ldots \ldots \ldots \ldots \ldots \ldots \ldots$ 4-11

4.8 INTERFACING SYSTEMS REQUIREMENTS $\ldots \ldots \ldots \ldots \ldots \ldots \ldots \ldots$ 4-11

4.8.1 Tempered Water System $\ldots \ldots \ldots \ldots \ldots \ldots \ldots \ldots \ldots$ 4-11

4.8.2 Tempered Water Cooling System . . . . . . . . . . . . 4-11

4.9 OPERABILITY $\ldots \ldots \ldots \ldots \ldots \ldots \ldots \ldots \ldots \ldots \ldots \ldots \ldots \ldots \ldots \ldots \ldots, 12$

4.9.1 Tempered Water System $\ldots \ldots \ldots \ldots \ldots \ldots \ldots \ldots \ldots \ldots$ 4-12

4.9.2 Tempered Water Cooling System $\ldots \ldots \ldots \ldots \ldots \ldots \ldots \ldots .4 .12$

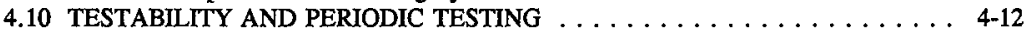

4.11 OPERATOR ACTIONS AND HUMAN FACTORS $\ldots \ldots \ldots \ldots \ldots \ldots \ldots$ 4-12

4.11.1 Tempered Water System . . . . . . . . . . . . . . . . 4-12

4.11 .2 Tempered Water Cooling System $\ldots \ldots \ldots \ldots \ldots \ldots \ldots \ldots .4-12$

4.12 SPECIAL CONSIDERATIONS $\ldots \ldots \ldots \ldots \ldots \ldots \ldots \ldots \ldots \ldots$ 4-13

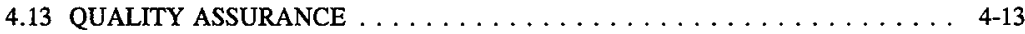

4.14 REQUIRED CODES AND STANDARDS $\ldots \ldots \ldots \ldots \ldots \ldots \ldots \ldots$ 4-13

4.14.1 Tempered Water System . . . . . . . . . . . . . . . . . . . . 4-13

4.14.2 Tempered Water Cooling System $\ldots \ldots \ldots \ldots \ldots \ldots \ldots \ldots$ 4-14

5.0 SYSTEM DESCRIPTION $\ldots \ldots \ldots \ldots \ldots \ldots \ldots \ldots \ldots \ldots \ldots \ldots \ldots$ 5-1

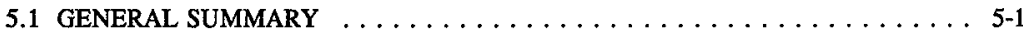

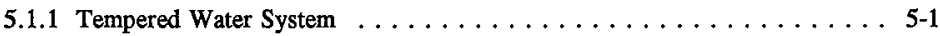

5.1 .2 Tempered Water Cooling System ............... 5-1

5.2 PIPING AND INSTRUMENTATION DIAGRAMS AND FLOW DIAGRAM $\ldots \ldots 5$ - 1

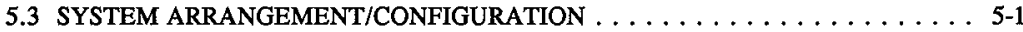

5.3.1 Tempered Water System $\ldots \ldots \ldots \ldots \ldots \ldots \ldots \ldots \ldots$ 5-1

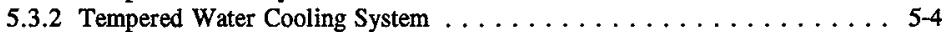

5.4 EXPLANATION OF HOW THE SYSTEM MEETS DESIGN REQUIREMENTS . . . 5-6

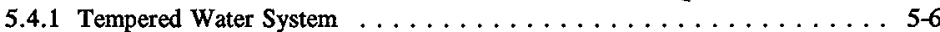

5.4 .2 Tempered Water Cooling System $\ldots \ldots \ldots \ldots \ldots \ldots \ldots \ldots$ 5-10

5.5 SYSTEM PARAMETERS AND SET POINTS $\ldots \ldots \ldots \ldots \ldots \ldots \ldots \ldots$ 5-12

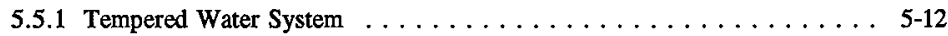

5.5.2 Tempered Water Cooling System $\ldots \ldots \ldots \ldots \ldots \ldots \ldots \ldots .6 \ldots \ldots$

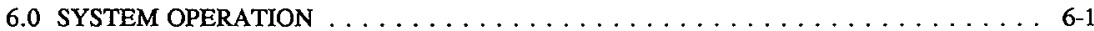

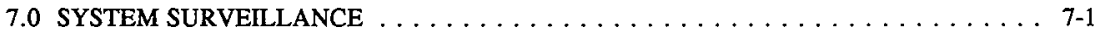

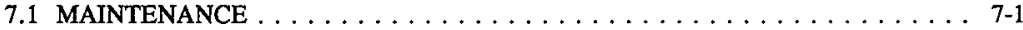

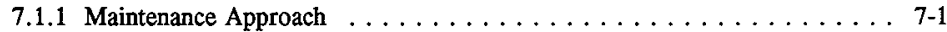

7.1.2 Corrective Maintenance and Preventive Maintenance ........ . 7-1

7.1 .3 Equipment Calibration . . . . . . . . . . . . . . . .

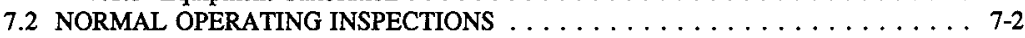




\section{CONTENTS (Continued)}

8.0 REFERENCES $\ldots \ldots \ldots \ldots \ldots \ldots \ldots \ldots \ldots \ldots \ldots \ldots \ldots \ldots \ldots$ 8 $8 \ldots \ldots \ldots \ldots$

8.1 INDUSTRY STANDARDS AND CODES $\ldots \ldots \ldots \ldots \ldots \ldots \ldots \ldots$ 8-1

8.2 GOVERNMENT DOCUMENTS $\ldots \ldots \ldots \ldots \ldots \ldots \ldots \ldots . \ldots \ldots$ 8-4

8.3 SPENT NUCLEAR FUEL PROJECT DOCUMENTS $\ldots \ldots \ldots \ldots \ldots \ldots \ldots 8-5$

8.4 DRAWINGS $\ldots \ldots \ldots \ldots \ldots \ldots \ldots \ldots \ldots \ldots \ldots \ldots . \ldots \ldots$ 8 5

APPENDIX

A DRAWING AND SPECIFICATION LISTS AND SUPPORTING INFORMATION $\ldots$ A-1 
SNF-3085 REV 0

\section{LIST OF TABLES}

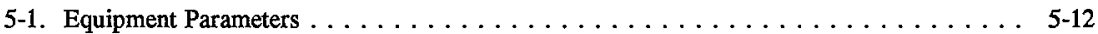

5-2. Components of the Tempered Water Cooling System $\ldots \ldots \ldots \ldots \ldots \ldots \ldots \ldots$ 5-13 


\section{LIST OF TERMS}

$\begin{array}{ll}\text { ALARA } & \text { as low as reasonably achievable } \\ \text { CHW } & \text { chilled water (system) } \\ \text { CVDF } & \text { Cold Vacuum Drying Facility } \\ \text { MCO } & \text { multi-canister overpack } \\ \text { MCS } & \text { monitoring and control system } \\ \text { PES } & \text { process equipment skid } \\ \text { PWC } & \text { process water conditioning (system) } \\ \text { SCIC } & \text { safety class instrumentation and control (system) } \\ \text { SSC } & \text { structure, system, and component } \\ \text { TBD } & \text { to be determined } \\ \text { TW } & \text { tempered water (system) } \\ \text { TWC } & \text { tempered water cooling (system) }\end{array}$




\subsection{INTRODUCTION}

This system design description addresses the tempered water (TW) system and the tempered water cooling (TWC) system. The discussion that follows will be limited to these systems. To gain an understanding of the TW and TWC systems please see Drawings H-1-83766, Cold Vacuum Drying Facility Process System P\&ID, and H-1-83768, CVDF Chilled \& Tempered Cooling Water System $P \& I D$.

This system design description, when used in conjunction with the other elements of the definitive design packages, provides a complete picture of the Cold Vacuum Drying Facility (CVDF). Elements of this design description include functions, requirements, and descriptions. Other documents comprising the definitive design of the tempered water system include:

- Project design requirements (HNF-SD-SNF-DRD-002)

- Safety Analysis Report (HNF-SD-SNF-SAR-002)

- Safety equipment list (HNF-SD-SNF-SEL-002)

- Contract drawings (see Appendix A)

- Procurement specification (see Appendix A)

- Supporting Data and Calculation Database (SNF-3001)

- Sequence of operations (see HNF-2356).

\subsection{SUMMARY DESCRIPTION OF EQUIPMENT}

\subsubsection{Tempered Water System}

The TW system contains a holding tank, water pump, water heater, water cooler, pressure control, safety relief and isolation valves, piping and instrumentation that provide temperature regulation as necessary during the multi-canister overpack (MCO) vacuum drying operating sequence. This system is credited with crucial safety functions that prevent thermal runaway accidents and hydrogen explosion both internal and external to the MCO. A schematic of the TW system equipment arrangement for a typical process bay is shown in Drawings H-1-82160, Cold Vacuum Drying Facility P\&ID Legend, and H-1-83766 (sheets 1 and 2). Interfaces with associated systems are also included in these drawings to show functionality.

The safety class components of the tempered water system include the cask-MCO seal ring, seismically qualified piping, level gauge, low water level safety switches, antisiphon valves, and high inlet water temperature safety switches.

The tempered water temperature switch is designed to detect elevated water temperature on the cask inlet line of the tempered water recirculation system. Upon detection of elevated temperatures, the system is designed to deactivate the tempered water heater and pump.

The annulus water level switch is designed to detect low water level and alarm to the control so manual corrective actions can be taken to realign the system and refill the annulus with water. 


\subsubsection{Tempered Water Cooling System}

This system contains pumps, a heat exchanger, a gas/liquid separator, an expansion tank, pressure control, safety relief and isolation valves, piping and instrumentation that provide cooling water to the TW system. A schematic of the TWC system equipment arrangement for a typical process bay is shown in Drawings H-1-82160, Cold Vacuum Drying Facility P\&ID Legend, and H-1-83768. Interfaces with associated systems are also included in these drawings to show functionality.

\subsection{ROLE OF SYSTEM IN PROCESS}

\subsubsection{Tempered Water System}

The tempered water system provides tempered water to the annulus between the MCO and the cask. The tempered water is heated or cooled depending on the step in the drying process. The tempered water system equipment maintains the $\mathrm{MCO}$ and its contents at the proper operating temperature during all stages of the MCO drying process.

\subsubsection{Tempered Water Cooling System}

The TWC system provides cooling water to the tempered water system. The cooling water provides the tempered water system with the ability to cool the cask-MCO assembly during the MCO cool-down, maintain the $\mathrm{MCO}$ at a given temperature without overheating, and place the cask-MCO assembly in a cool-down mode during an accident scenario. The TWC system exchanges the heat from the tempered water system with the chilled water (CHW) system.

\subsection{TECHNICAL RESPONSIBILITY OF SYSTEM DESIGN DESCRIPTION}

The CVDF system design authority engineer is responsible for the accuracy and technical content of this system design description. Any questions should be addressed to the system design authority engineer. 


\subsection{SYSTEM DEFINITION}

\subsection{GENERAL DESCRIPTION}

The TW system and the TWC system process sequence is controlled by a programmable logic controller that is a part of the overall CVDF control system.

\subsubsection{Tempered Water System}

There is one TW system for each processing bay that maintains an adequate level of water in the cask-MCO annulus. The tempered water is recycled through the annulus with a water pump. The tempered water is heated by the water heater during the MCO heat-up steps and cooled by the water cooler during the $\mathrm{MCO}$ cooldown step. The tempered water heats and cools the MCO to meet the required temperature setpoints.

\subsubsection{Tempered Water Cooling System}

There is one TWC system that provides cooling water for all processing bays. The cooling water is recycled with a set of parallel water pumps and cooled by a heat exchanger supplied by chilled water from the CHW system.

\subsection{SYSTEM BOUNDARIES}

\subsubsection{Tempered Water System}

The TW system equipment is mounted on the process equipment skid (PES) located under the mezzanine in each bay. TW system equipment comprises pumps TW-P-3*14, expansion tank TW-TK-3*12, electric heater TW-HTR-3*11, cooler/heat exchanger TW-CLR-3*10, and Cask seal ring assembly TW-SE-1*13. All necessary instrumentation is found either on the PES or process connection lines to the MCO. Piping connections are made through a port on the bottom of the cask and through the seal ring on the top of the MCO. Interface piping between the cask and the PES first passes through the process hood support stand where some TW system instrumentation and valves are located.

Each PES occupies a space $5.49 \mathrm{~m}(18 \mathrm{ft})$ east-west, $1.83 \mathrm{~m}(6 \mathrm{ft})$ north-south, and $3.05 \mathrm{~m}(10$

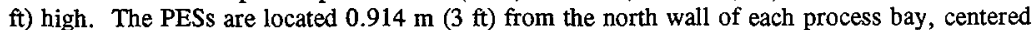

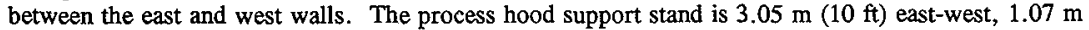

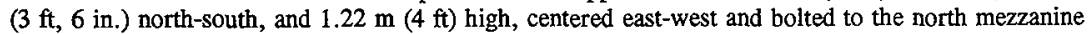
overhanging each process bay.

\subsubsection{Tempered Water Cooling System}

All TWC system equipment is located in the mechanical equipment area in mechanical room (room no. 207) of the CVDF. TWC system equipment comprises pumps TWC-P-7055 and 
TWC-P-7058, expansion tank TWC-TK-7056, separator TWC-SEP-7063, and heat exchanger TWC-HX-7051. The cooling water is piped to each process bay and each TW system cooler (TW-CLR-3*10).

\subsection{SYSTEM INTERFACES}

\subsubsection{Tempered Water System}

The TW system has ten major interfaces with the CVDF.

\subsubsection{Cask-MCO}

The TW system interfaces with the cask-MCO annulus. Line TW-*01-SS-1 1/2" supplies the annulus. Line TW-*02-SS-11/2" returns flow from the annulus to the tempered water system. Line TW-*02-SS-11/2" is connected to the Cask seal ring assembly, TW-SE-1*13, which inturn is bolted to the top of the cask.

\subsubsection{Monitoring and Control System and Safety-Class Instrumentation and Control System}

The TW system interfaces with the monitoring and control system (MCS) and the safety class instrumentation and control (SCIC) system. MCS instrumentation and control wiring is per ANSI/IEEE-577, Standard Requirements for Reliability Analysis in the Design and Operation of Safety Systems for Nuclear Power Generating Stations. SCIC system instrumentation and control wiring is per ANSI/IEEE-308, Standard Criteria for Class $1 E$ Power Systems for Nuclear Generating Stations; ANSI/IEEE-338, Standard Criteria for the Periodic Surveillance Testing of Nuclear Power Generating Station Safety Systems; ANSI/IEEE-379, Standard Application of the Single-Failure Criterion to Nuclear Power Generating Station Safety Systems; ANSI/IEEE-384, Standard Criteria for Independence of Class IE Equipment and Circuits; and ANSI/IEEE-603, Standard Criteria for Safety Systems for Nuclear Power Generating Stations.

\subsubsection{Electrical System}

The TW system interfaces with the CVDF electrical system. All electrical power is supplied through hard wired connections with facility electrical as needed.

\subsubsection{Tempered Water Cooling System}

The TW system interfaces with the TWC system. The TWC system provides chilled water to TW-CLR-3*10 with line TWC-*01-SS-1 1/2". Line TWC-SS-*02-SS-1/2" returns the water to the TWC system supply. 


\subsubsection{Process Equipment Skid and Process Hood Support Stand}

The TW system interfaces with the PES and the process hood support stand. All TW system equipment and portions of the piping and instrumentation are mounted on to the PES or the process hood support stand.

\subsubsection{HVAC System}

The TW system interfaces with the CVDF heating, ventilation, and air conditioning system. Holding tank TW-TK-3*12 is vented by PV-*02-SS-1".

\subsubsection{Facility Deionized Water System}

The TW system interfaces with the CVDF deionized water system. DI-*02-SS-1" supplies flushing water and make-up water to holding tank TW-TK-3*12.

\subsubsection{Facility Compressed Air System}

The TW system interfaces with the CVDF compressed air system. CA-*01-SS-1" supplies TW-*02-SS-1 1/2" with cask-MCO annulus drying air.

\subsubsection{Facility Instrument Air System}

The TW system interfaces with the CVDF instrument air system. All gas-operated valves are supplied from the IA-*01-SS-1" connection to the instrument air header. In addition, line IA-*02-ST-1/4" supplies the inflatable seal ring between the cask and MCO at the Cask seal ring assembly, TW-SE-1*13.

\subsubsection{Process Water Conditioning System}

The TW system interfaces with the CVDF process water conditioning (PWC) system. PWC-*03-SS-1" and PWC-*04-SS-1" connect to low point drains on the TW system at the PES and at the cask lower connction port for draining water to the PWC system.

\subsubsection{Tempered Water Cooling System}

The TWC system has seven major interfaces with the CVDF.

\subsubsection{Civil Support Structrures}

The TWC system interfaces with the CVDF building. The TWC system equipment is bolted to the floor of mechanical room 207. The TWC system interfaces with the MCS. MCS instrumentation and control wiring is per ANSI/NFPA 70, National Electrical Code; ANSI/IES RP1, Practice for Office Lighting; and ANSI/IES RP7, Practice for Industrial Lighting. 


\subsubsection{Electrical System}

The TWC system interfaces with the CVDF electrical system. All electrical requirements are supplied through hard wired connections with facility electrical as needed.

\subsubsection{Facility Chilled Water System}

The TWC system interfaces with the CHW system. The CHW system provides chilled water to TWC-HX-7051 with line CHW-020-CT-21/2". Line CHW-SS-021-CT-2 $\frac{1 / 2}{2}$ returns the water to the CHW system supply.

\subsubsection{Tempered Water System}

The TWC system interfaces with the TW system. The TWC system provides cooling water to coolers TW-CLR-3*10 via line TWC-*01-SS-11/2*.

\subsubsection{HVAC and Facility Monitoring and Control Systems}

The TWC system interfaces with the HVAC and Facility monitoring and control systems (MCS). MCS instrumentation and control wiring is per ANSI/IEEE-577, Standard Requirements for Reliability Analysis in the Design and Operation of Safety Systems for Nuclear Power Generating Stations.

\subsubsection{Facility Instrument Air System}

The TWC system interfaces with the facility instrument air system, IA is supplied through line IA-*03-SS-1" to pneumatically-operated valve, TWC-GOV-3*01, on the PES.

\subsubsection{Potable Water Systems}

The TWC system interfaces with the potable to provide make up water as needed through line NPW-003-CT-3/4". 
SNF-3085 REV 0

This page intentionally left blank. 


\subsection{SYSTEM FUNCTION}

\subsection{SYSTEM CLASSIFICATION}

\subsubsection{Tempered Water System}

A portion of the TW system contains safety-class piping, antisiphon valves, temperature monitors, and level indicators that are used in conjunction with the SCIC to ensure passive cooling during accident conditions. TW piping between the cask port and the valves and piping components on the process hood support stand form the primary barrier for release of annulus water. These are considered safety class primary boundaries and are designed to performance category 3 standards as defined in the DOE-STD-1020-94, Natural Phenomena Hazards Design and Evaluation Criteria for Department of Energy Facilities. The rest of the TW system is designated general service and is designed and tested to those standards. Designations are given as required by HNF-SD-SNF-SAR-002, Safety Analysis Report for the Cold Vacuum Drying Facility, Phase 2, Supporting Installation of Processing Systems. Safety and Performance category designations of the equipment, piping, valves and instruments, shown in the piping and instrumentation diagrams is given in HNF-SD-SNF-SEL-002, Spent Nuclear Fuel Project Cold Vacuum Drying Facility Safety Equipment List.

\subsubsection{Safety-Class Piping and Equipment}

The piping, valves and instruments in the TW system from anti-siphon valves TW-FCV-1*22/$1 * 23$ (safety class) to the Cask on TW-*01-SS-1 1/2" and on TW-*02-SS-1 $1 / 2^{*}$, including the valves and piping components, are designated safety class and performance category 3 . There is a safety class and performance category 3 designation for the process hood support stand that supports this TW system equipment.

\subsubsection{General Services Piping and Equipment}

The support structure for the TW system and all equipment contained within it are designated general services and all structural components and equipment anchorage are performance category 2 for the PES.

\subsubsection{Tempered Water Cooling System}

All TWC system valves, components, instrumentation, controls, and support structures are designated general service and are designed and qualified for performance category 2 as defined in DOE-STD-1020-94. Safety and Performance category designations of the equipment, piping, valves and instruments, shown in the piping and instrumentation diagrams is given in HNF-SD-SNF-SEL-002, Spent Nuclear Fuel Project Cold Vacuum Drying Facility Safety Equipment List. 


\subsection{CVDF SAR SAFETY FUNCTIONS}

\subsubsection{Tempered Water System}

The CVDF SAR, HNF-SD-SNF-SAR-002, defines the safety functions for the TW system. These functions are defined in Section 4.3.5.1 of the CVDF SAR and are summarized as follows.

1. Provide a hydraulic boundary, connections, and sealing surface for TW components to retain water in cask annulus (Prevention of runaway corrosion reaction by maintaining water in cask annulus at all times). An MCO runaway thermal corrosion reaction is prevented with the use of active detection and prevention features. These features comprise instrumentation monitoring the conditions important to maintaining thermal stability during the process.

2. Detect low annulus water level and provide alarm to operators, detect high inlet temperature and provide signal to SCIC to cut power to TW heater and pump. The instrumentation has activation logic associated with initiating a safe shutdown upon indication of unsafe thermal conditions.

3. Perform the above functions to prevent or mitigate the safety-significant consequences of the MCO gaseous release, MCO internal hydrogen explosion or external hydrogen explosion. Detect high water temperature and low level in cask-MCO annulus and provide signal to SCIC system to cut power to TW pump and heater

4. Primary confinement. (Contaminated effluents from cask annulus water.) The TW system provides a barrier that separates any potential radioactive material contained in the Cask-MCO annulus and the process piping from spaces bounded by structures whose failure offers a path for a radioactive release into the CVDF or stack stream.

\subsubsection{Tempered Water Cooling System}

The TWC system has no SAR related safety functions.

\subsection{Non-SAR SAFETY FUNCTIONS}

\subsubsection{Radiation Protection}

The following list of radiation protection features have been considered during the design of the TW and TWC systems to meet ALARA exposure requirements and design guidelines.

Engineering Controls. Engineering controls that have been considered to achieve ALARA goals include the following:

- Confinement systems such as process piping, vessels, and structural enclosures

- Ventilation systems that ensure negative pressure and flow toward the areas with the highest contamination risk 
- Compartmentalization to isolate higher risk areas

- Equipment location and arrangement so that servicing and replacement can be accomplished away from high risk areas

- Waste treatment and handling systems to minimize releases

- Inclusion of decontamination features

- Automation of the process so that operators need not be present in the radiation field to operate the process

- Arrangement designed so as to maximize the distance between operators and sources

- Traps where radioactive material can accumulate in the systems minimized and provisions included for periodic decontamination of the process system

- Local shielding, including piping and vessel materials, to minimize source terms

- Communication and observation systems to monitor operators when in the radiation field.

Maintenance Features. Maintenance features that have been considered to reduce exposure of personnel are as follows:

- Use of modular construction to speed replacement

- Provision for decontamination before beginning a replacement; ease of decontamination has been considered when selecting equipment

- High or enhanced system performance that reduces maintenance requirements

- Selection of components that do not require lubrication or regular service.

\subsubsection{Natural Phenomena Hazard Mitigation (Seismic)}

The safety class TW system support structure (Process Hood Stand) and attachments are performance category 3. All general services TW and TWC system structures, systems, and components (SSCs) have been evaluated for their potential to prevent safety class SSCs from performing their functions.

\subsubsection{Worker Safety Hazards Protection}

The TW and TWC systems design has been evaluated against and complies with the required codes, standards, and regulations for industrial safety and hygiene. 


\subsection{ENVIRONMENTAL FUNCTIONS}

The TW and TWC system piping and equipment provide essential support to environmental SSCs by preventing the release of contaminants within the CVDF. The CVDF provides protection from seismic disturbance, high winds, and tornado winds. The safety basis internal conditions and specific external environmental conditions for safety are listed in HNF-SD-SNF-SEL-002. The VPS is protected from high winds and tornadoes by the structure of the CVDF. Flooding, lightning, and snow load protections are provided by the placement and design of the CVDF.

\subsubsection{Tempered Water System}

The TW system cask connections and standpipe piping, valves, and instrumentation and control are seismically qualified for performance category 3 . All other TW system piping, equipment, and support structures are seismically qualified for performance category 2 . All TW system structures, systems, and components (SSCs) have been evaluated for potential to prevent safety class SSCs from performing their functions.

\subsubsection{Tempered Water Cooling System}

All TWC system components are designed to function under normal environmental conditions. The TWC system piping and equipment have been assigned performance category 1 and are not required to function after a seismic event. 
SNF-3085 REV 0

This page intentionally left blank. 
SNF-3085 REV 0

\subsection{SYSTEM REQUIREMENTS}

\subsection{OPERATIONAL AND FUNCTIONAL REQUIREMENTS AND BASIS FOR REQUTREMENTS}

The following describes the safety performance requirements and the basis for those requirements. The requirements, identified in italics, are excerpted from HNF-SD-SNF-DRD-002, Cold Vacuum Drying Facility Design Requirements.

\subsubsection{Tempered Water System}

\subsubsection{HNF-SD-SNF-DRD-002, Section 5.3.4a.}

A. Process Requirement--The required flow rate of the TW system shall be a minimum of $56.8 \mathrm{~L} / \mathrm{min}(15 \mathrm{gal} / \mathrm{min})$ and shall have a design gauge pressure of $138 \mathrm{kPa}\left(20 \mathrm{lb} / \mathrm{in}^{2}\right)$ with a maximum allowable gauge pressure of $172 \mathrm{kPa}\left(25 \mathrm{lb} / \mathrm{in}^{2}\right)$ in the cask-MCO annular space.

B. Basis--The minimum required flowrate of $56.8 \mathrm{~L} / \mathrm{min}(15 \mathrm{gal} / \mathrm{min})$ is based on heat transfer requirements for the cask-MCO assembly. The seal ring is designed to withstand a pressure of $172 \mathrm{kPa}\left(25 \mathrm{lb} / \mathrm{in}^{2}\right)$ and provides primary containment of the tempered water within the cask-MCO annulus.

\subsubsection{HNF-SD-SNF-DRD-002, Section 5.3.4b.}

A. Process Requirement--During vacuum drying, the $T W$ system shall be able to heat the $\mathrm{MCO}$ and maintain it at a temperature of approximately $50^{\circ} \mathrm{C}\left(122^{\circ} \mathrm{F}\right)$ for a continuous period of not more than two days per drying operation to assist in the removal of residual water from the $M C O$.

B. Basis--The optimum temperature for the vacuum and purge drying steps to maximize evaporation and minimize fuel reaction has been determined to be $50^{\circ} \mathrm{C}\left(122{ }^{\circ} \mathrm{F}\right)$.

\subsubsection{HNF-SD-SNF-DRD-002, Section 5.3.4c.}

A. Process Requirement--The design temperature range is specified at $10^{\circ} \mathrm{C}$ to $50^{\circ} \mathrm{C}(50$ ${ }^{\circ} \mathrm{F}$ to $122^{\circ} \mathrm{F}$ ).

B. Basis--The optimum temperature for the offgas monitoring and shipping acceptance test to maximize offgas formation without exceeding safety limits for fuel reaction has been determined to be $46^{\circ} \mathrm{C}$.

\subsubsection{HNF-SD-SNF-DRD-002, Section 5.3.4d.}

A. Process Requirement--After vacuum drying of the $M C O$, the $T W$ system shall be required to cool down the $M C O$ and cask to $15^{\circ} \mathrm{C}\left(59^{\circ} \mathrm{F}\right)$ at the water inlet, the required temperature for shipping. 
B. Basis-The optimum temperature for dry storage of a processed MCO to minimize offgas formation has been determined to be $15^{\circ} \mathrm{C}\left(59^{\circ} \mathrm{F}\right)$.

\subsubsection{HNF-SD-SNF-DRD-002, Section 5.3.4e.}

A. Process Requirement-The TW system shall be required to interface with the MCS to allow for computer control of MCO heating and cooling during all stages of the drying operation.

B. Basis-The automation of the process allows the operators to control the process without being present in the radiation field. The heating and cooling steps of the process are best achieved using an MCS to control the heating and cooling rates. The CVDF MCS can automatically adjust the heater setpoint based on the heater outlet temperature and tempered water flow rate. The MCS controls the cooling rate by adjusting the cooling water flow based on the cooler outlet temperature and tempered water flowrate.

\subsubsection{HNF-SD-SNF-DRD-002, Section 5.3.4f.}

A. Process Requirement-Water heating shall be accomplished with an electric heater. Heater power shall be controlled with a silicon controlled rectifier. Water cooling shall be accomplished with a heat exchanger that transfers heat to a central CHW system. Deionized water shall be used for the make-up water.

B. Basis--An electric heater with a silicon-controlled rectifier provides an effective means of controlling the heating rate of the system. A central cooling water system provides an efficient method of cooling all tempered water within the CVDF. Deionized water as make-up ensures reduction of contaminants in the tempered water to react with the spent nuclear fuel in the event of a leak in the MCO cask assembly.

\subsubsection{HNF-SD-SNF-DRD-002, Section 5.3.4g.}

A. Process Requirement--Each cask will arrive with water in the annulus. Addition of the cask water to the system will require periodic release of water to maintain the system fill level. The TW system drain leads to the process water conditioning (PWC) system. The system shall have a method of draining the cask without draining the system. Either a pump or gas pressure may be used to move the water out of the cask.

B. Basis--Any water drained from the TW system is routed to the PWC system for treatment because there is the possibility of contamination of the tempered water. To minimize the volume of water treated by the PWC system, the MCO cask assembly is drained separately from the TW system.

\subsubsection{HNF-SD-SNF-DRD-002, Section 5.3.4h.}

A. Process Requirement-There shall be three process system connections to the cask. These shall be water and gas tight connect fittings that mate with fittings provided on the cask. There shall be a valve/pressure gauge arrangement in the upper connection to allow for measurement and bleed-off of the cask pressure when the connection is made. 
B. Basis-A process connection to the cask lid is required to check and bleed off any pressure before removal of the cask lid and installation of the seal ring. Measurement of the cask lid pressure is required to inform the operator that the system is at a safe pressure because the bleeding and purging operations are manual. Two process connections are required on the cask after the seal ring is installed to provide an inlet and outlet for the tempered water.

\subsubsection{HNF-SD-SNF-DRD-002, Section 5.3.4i.}

A. Process Requirement-TheTW system shall be designed to maintain liquid in the cask annulus during design basis earthquakes, all credible accidents, and process upsets.

B. Basis--The cask-MCO annulus must be filled with water at all times including after upsets or accidents to provide thermal protection of the $\mathrm{MCO}$ and its contents. Without water in the annulus, the equipment cannot control the temperature of the MCO.

\subsubsection{HNF-SD-SNF-DRD-002, Section 5.3.4j.}

A. Process Requirement--Water in the system may become slightly contaminated. There shall be provision for periodic sampling the water and flushing of the system with demineralized water.

B. Basis--Sampling of the TW system is required to monitor the water for contamination. Any contamination of the tempered water can be a sign of a leak in the cask-MCO assembly. In the event of contamination, the deionized water can be used to flush the contaminated water from the TW system.

\subsubsection{HNF-SD-SNF-DRD-002, Section 5.3.4k.}

A. Process Requirement-The ring shall fit on the cask and be held in place with bolts using the bolt holes that are used for attaching the cask lid to the cask.

B. Basis--The seal ring provides primary confinement of the tempered water within the cask-MCO annulus. The seal ring is attached to the cask using existing holes. Use of the existing holes minimizes the changes in the cask design that are needed to accommodate the seal ring.

\subsubsection{HNF-SD-SNF-DRD-002, Section 5.3.41.}

A. Process Requirement-The ring includes a seal that retains water in the annulus while it is being circulated through the annulus with a maximum gauge pressure of $172 \mathrm{kPa}$ ( $25 \mathrm{lbf}\left(\mathrm{in}^{2}\right)$.

B. Basis-The maximum pressure of $172 \mathrm{kPa}\left(25 \mathrm{lbf} / \mathrm{in}^{2}\right)$ is based on the strength of the inflatable seal ring at the design pressure. 


\subsubsection{HNF-SD-SNF-DRD-002, Section 5.3.4m.}

A. Process Requirement--The center of the seal ring shall open to allow process system connection access to the ports on the top of the MCO. The seal ring thickness shall be sized to resist the uplift load due to any credible water pressure from the circulating water within the cask annulus.

B. Basis-The seal ring is designed in a donut shape with an open center because it is required to be in place before the MCO valves are opened. The seal ring is the primary confinement of the tempered water within the cask-MCO annulus, therefore it is designed to withstand the expected pressure of the tempered water in the annulus.

\subsubsection{HNF-SD-SNF-DRD-002, Section 5.3.4n.}

A. Process Requirement--The seal ring is not required to provide any shielding for radiation streaming from the cask annulus.

B. Basis--The MCO and cask design provide the required shielding for radiation streaming from the cask annulus.

\subsubsection{Tempered Water Cooling System}

\subsubsection{HNF-SD-SNF-DRD-002, Section 6.6.4.2a.}

A. Functional Performance Requirement-A central facility chilled water cooling system shall be designed to serve ventilation cooling loads, TWS heat exchangers, and the VPS condenser. The system concept includes packaged chiller units, circulating pumps, associated piping, instrumentation, and controls.

B. Basis--The use of a facility chilled water cooling system minimizes the number of equipment, piping, and instrumentation. A facility chilled water cooling system is more efficient than cooling systems for each individual process bay.

\subsubsection{HNF-SD-SNF-DRD-002, Section 6.6.4.2c.}

A. Functional Performance Requirement--Expansion tanks shall be designed to the ASME Code, Section VIII, and shall include gauge glasses, drain valves, vent valves, and pressure relief valves.

B. Basis--Because safety relief valve SRV-7063 is set at $50 \mathrm{lbf} / \mathrm{in}^{2}$ gauge, the expansion tank may experience high pressures. This code was specified to ensure standardization of design and construction as well as operator safety.

\subsubsection{HNF-SD-SNF-DRD-002, Section 6.6.4.2d.}

A. Functional Performance Requirement-Make-up water shall be drawn from the potable water supply through a reduced pressure backflow assembly. 
B. Basis--A backflow prevention device maintains isolation between systems. In this case, it prevents TWC system water from contaminating the potable water system.

\subsubsection{HNF-SD-SNF-DRD-002, Section 6.6.4.2f.}

A. Functional Performance Requirement--All chilled water piping shall be designed and constructed in accordance with ANSI/ASME B31.3 or ANSI/ASME B31.9.

B. Basis--Design of a chilled water piping system is included in the scope of ANSI/ASME B31.9, General Services Piping Code. This code was specified to ensure standardization of design and construction as well as operator safety.

\subsubsection{HNF-SD-SNF-DRD-002, Section 6.6.4.2g.}

A. Functional Performance Requirement--Chilled water shall be provided from the facility chilled water cooling system.

B. Basis--The use of a facility chilled water cooling system minimizes the number of equipment, piping, and instrumentation. A facility chilled water cooling system is more efficient than cooling systems for each individual process bay.

\subsubsection{HNF-SD-SNF-DRD-002, Section 6.6.4.2h.}

A. Functional Performance Requirement--Chilled water shall not come in direct contact with process equipment surfaces (such as the MCO) that may be contaminated.

B. Basis--The use of intermediate cooling systems between the MCO and the CHW system minimizes the likelihood that the facility systems will be contaminated. Therefore, any contamination is isolated within the process bays.

\subsection{CIVIL AND STRUCTURAL REQUIREMENTS}

\subsubsection{Tempered Water System}

The TW system cask connections and standpipe piping, valves, instrumentation, controls, and support structures required to perform safety-class prevention of an MCO thermal runaway reaction are designed and qualified for performance category 3 as defined in DOE-STD-1020-94.

All other TW system tanks, valves, components, instrumentation, controls, and support structures required to perform the safety-significant primary confinement functions are designed and qualified for performance category 2 as defined in DOE-STD-1020-94. 


\subsubsection{Tempered Water Cooling System}

All TWC system valves, components, instrumentation, controls, and support structures are designated general service and are designed and qualified for performance category 2 as defined in DOE-STD-1020-94.

\subsection{MECHANICAL REQUIREMENTS}

Based on the safety category designations the codes and standards required for equipment, piping and valves of the TW and the TWC systems are tabulated in HNF-SD-SNF-SEL-002, Spent Nuclear Fuel Project Cold Vacuum Drying Facility Safety Equipment List. To avoid duplication, this information is not repeated here.

\subsection{MATERIALS REQUIREMENTS}

\subsubsection{Tempered Water System}

The materials of construction for the various SSCs meet the following requirements as defined by the procurement specification.

- American Society for Testing and Materials (ASTM)

A36 Standard Specification for Structural Steel

A105 Standard Specification for Forgings, Carbon Steel, for Piping Components

A106 Standard Specification for Seamless Carbon Steel Pipe for High-Temperature Service

A182 Standard Specification for Forged or Rolled Alloy-Steel Pipe Flanges, Forged Fittings, and Valves and Parts for High-Temperature Service

A197 Standard Specification for Cupola Malleable Iron

A240 Standard Specification for Heat-Resisting Chromium and Chromium-Nickel Stainless Steel Plate, Sheet, and Strip for Pressure Vessels

A269 Standard Specification for Seamless and Welded Austenitic Stainless Steel Tubing for General Service

A276 Standard Specification for Stainless and Heat-Resisting Steel Bars and Shapes

A307 Standard Specification for Carbon Steel Bolts and Studs, 60,000 PSI Tensile Strength

A312 Standard Specification for Seamless and Welded Austenitic Stainless Steel Pipes 


\section{SNF-3085 REV 0}

A354 Standard Specification for Quenched and Tempered Alloy Steel Bolts, Studs and other Externally Threaded Fasteners

A479 Standard Specification for Stainless and Heat-Resisting Steel Bars and Shapes for Use in Boilers and other Pressure Vessels

A480 Standard Specification for General Requirements for Flat-Rolled Stainless Heat-Resisting Steel Plate, Sheet, and Strip

A500 Standard Specification for Cold-Formed Welded and Seamless Carbon Steel Structural Tubing in Rounds and Shapes

A563A Standard Specification for Carbon and Alloy Steel Nuts

E498 Leaks Using the Mass Spectrometer Leak Detector or Residual Gas Analyzer in the Tracer Probe Mode, Methods of Testing

F593 Standard Specification for Stainless Steel Bolts, Hex Cap Screws, and Studs

F594 Standard Specification for Stainless Steel Nuts.

\subsubsection{Tempered Water Cooling System}

The materials of construction for the various SSCs shall meet the following requirements as defined by Specification Sections 15010, 15510, and 15540 .

\subsubsection{Chilled Water Piping.}

- Copper tubing: ASTM B88, Tube, Water, Seamless Copper, Type L, hard drawn.

- Fittings: ASME B16.22, Wrought Copper and Copper Alloy Solder-Joint Pressure Fittings, solder wrought copper.

- Tee connections: mechanically extracted collars with notched and dimpled branch tube.

- Joints: Solder, lead-free.

\subsubsection{Equipment Drains and Overflows.}

- Copper tubing: ASTM B88, Type L, hard drawn

- Fittings: ASME B16.22, solder wrought copper

- Joints: solder, lead-free.

\subsubsection{Unions, Flanges, and Couplings.}

- Unions for pipe $5.08 \mathrm{~cm}$ (2 in.) or less - copper pipe: bronze, soldered joints. 
- Flanges for pipe $5.08 \mathrm{~cm}$ (2 in.) or less - copper pipe: bronze; gaskets: 0.06 in. thick preformed neoprene.

- Dielectric connections - Union with galvanized or plated steel threaded end, copper soldered end, water impervious isolation barrier.

\subsubsection{Gate Valves.}

- Up to and including $5.08 \mathrm{~cm}$ ( 2 in.): bronze body, bronze trim, screwed rising stem, handwheel, inside screw with backseating stem, wedge disc, alloy seat rings, solder or threaded ends.

- Over $5.08 \mathrm{~cm}$ ( 2 in.): iron body, bronze trim, bolted bonnet, rising stem, handwheel, outside screw and yoke, solid wedge disc with bronze seat rings, flanged or grooved ends.

\subsubsection{Globe or Angle Valves.}

- Up to and including $5.08 \mathrm{~cm}$ ( 2 in.): bronze body, bronze trim, rising stem and handwheel, inside screw with backseating stem, renewable composition disc, and bronze seat solder or threaded ends.

- Over $5.08 \mathrm{~cm}$ ( 2 in.): iron body, bronze trim, bolted bonnet, rising stem, handwheel, outside screw and yoke rotating plug-type disc with renewable seat ring and disc, flanged ends.

\subsubsection{Ball Valves.}

- Up to and including $5.08 \mathrm{~cm}$ (2 in.): bronze one-piece body, stainless steel ball, Teflon ${ }^{1}$ seats and stuffing box ring, lever handle with balancing stops, solder or threaded ends.

- Over $5.08 \mathrm{~cm}(2 \mathrm{in.})$ : cast steel body, chrome-plated steel ball, Teflon seat and stuffing box seats, lever handle.

\subsubsection{Plug Valves.}

- Up to and including $5.08 \mathrm{~cm} \mathrm{(2} \mathrm{in.):} \mathrm{bronze} \mathrm{body,} \mathrm{bronze} \mathrm{tapered} \mathrm{plug,} \mathrm{full} \mathrm{port}$ opening, nonlubricated, Teflon packing, threaded ends. Operator: one plug valve wrench for every 10 plug valves, minimum of one.

- Over $5.08 \mathrm{~cm}$ ( 2 in.): cast iron body and plug, full port opening, pressure lubricated, Teflon packing, flanged ends. Operator: each plug valve with a wrench with set screw.

${ }^{1}$ Teflon is a registered trademark of E.I. du Pont de Nemours and Company, Wilmington, Delaware. 


\subsubsection{Swing Check Valves.}

- Up to and including $5.08 \mathrm{~cm}$ (2 in.): bronze body, bronze trim, bronze rotating swing disc, with composition disc, solder or threaded ends.

- Over $5.08 \mathrm{~cm}$ ( 2 in.): iron body, bronze trim, bronze or bronze faced rotating swing disc, renewable disc and seat, flanged ends.

\subsubsection{Spring Loaded Check Valves.}

- Iron body, bronze trim, split plate, hinged with stainless steel spring, resilient seal bonded to body, wafer, or threaded lug ends.

\subsubsection{Vertical Single Stage Split-Case Pumps.}

- Casing: cast iron, with suction and discharge gage ports, renewable bronze casing wearing rings, seal flush connection, drain plug, flanged suction, and discharge.

- Impeller: bronze, fully enclosed, keyed to motor shaft extension.

- Shaft: stainless steel.

- Seal: Teflon gaskets must be provided between the impeller hub and the shaft sleeves to prevent purmped liquid from corroding the shaft.

\subsection{INSTRUMENTATION AND CONTROLS}

\subsubsection{Tempered Water System}

The TW system shall interface with the MCS and SCIC system for instrumentation and control. The TWC system shall interface with the MCS for instrumentation and control. All instrumentation and control power shall be nonsafety supplied by the facility uninterruptible power supply. Isolation from power transients and failures is provided such that safety functions are accomplished under power loss or transient conditions.

- Local electronic transmitters for remote indication is provided for process equipment and includes local indication whenever possible.

- For major electrical equipment, a local control station is provided. A switch is provided to allow for "hand" (local on), "off," and "remote" (from the MCS). When this switch is taken out of "remote," a notification shall be provided to the control room.

- Engineering units shall be used wherever possible. The use of $0 \%$ to $100 \%$ range indication shall be avoided. The range of equipment shall cover both the expected normal range as well as upset, emergency, and faulted conditions if the instrument is used under these conditions. 
- Instruments shall be capable of calibration without the need to open the fluid boundary. The use of wells, isolation valves, and test ports shall be used whenever possible.

- Panel design shall consider the likelihood of surface radioactive contamination and water sprays. In locations where this possibility exists, watertight enclosures shall be used.

- Panels larger than $203 \mathrm{~mm}$ (8 in.) in length or height shall use hinged door covers. For all instrument racks, the access doors shall be removable.

- The use of hard wired interlocks shall be appropriate to the condition being protected against. For the most part, MCS interlocks shall be used (software interlocks).

However, for the protection of personnel or equipment that sustains significant damage, hard interlocks may be used.

- Standardization of the selection of instrumentation and control equipment is critical to maintenance and cost-effectiveness. All common items within the CVDF shall be the same make and model whenever possible.

- The need for "emergency off" buttons shall be reviewed and documented, and use of such buttons implemented, based on the impact to personnel, equipment, or program goals. The implementation of this function may be hard wired or performed by the MCS via local switches. The emergency button shall be a mushroom-type switch allowing for rapid activation.

\subsection{RELIABILITY REQUIREMENTS}

\subsubsection{Tempered Water System}

The actual life of the project is scheduled to be two years, and the design life is five years. Adequate spare parts per the maintenance manuals are on hand to handle any downtime situation in a timely manner.

\subsection{ENVIRONMENTAL REQUIREMENTS}

The TW and TWC systems are protected from high winds and tornadoes by the structure of the CVDF. Flooding, lightning, and snow load projections are provided by the placement and design of the CVDF.

\subsubsection{Tempered Water System}

All safety significant and safety class components are designed to function under worst case internal and external environmental conditions. The safety significant TW system piping and equipment on the PES are seismically qualified for performance category 2 and are not required to function after a seismic event. The safety class TW system cask connections and standpipe piping are seismically qualified for performance category 3 and be required to function after a seismic event. 


\subsubsection{Tempered Water Cooling System}

All general service components shall be designed to function under normal environmental conditions. The TWC system piping and equipment are seismically qualified for performance category 2 and not required to function after a seismic event.

\subsection{INTERFACING SYSTEMS REQUIREMENTS}

\subsubsection{Tempered Water System}

- All TW system instrumentation and control wiring to the MCS is per ANSI/IEEE-577 to meet safety significant requirements.

- All TW system instrumentation and control wiring to the SCIC system is per ANSI/IEEE-308, ANSI/IEEE-338, ANSI/IEEE-379, ANSI/IEEE-384, and ANSI/IEEE-603 to meet safety class requirements.

- All TW system interfaces with the CVDF electrical system are through hard-wired connections with facility single-phase, $120 \mathrm{~V}$ (ac) electrical as needed. All wiring is per ANSI/NFPA 70.

- The CVDF instrument air system supplies the gas operated valves in the TW system with $90 \mathrm{lbf} / \mathrm{in}^{2}$ gauge instrument air via line IA-*01-SS-1/2".

- The CVDF deionized water system supplies $5 \mathrm{gal} / \mathrm{min}$ of $20 \mathrm{lbf} / \mathrm{in}^{2}$ gauge water to flush holding tank TW-TK-3*12 and provide makeup water as needed via line DI-*02-SS-1".

- The CVDF compressed air system supplies 5 standard $\mathrm{ft}^{3} / \mathrm{min}$ of $20 \mathrm{lbf} / \mathrm{in}^{2}$ gauge compressed air for draining and drying of the cask-MCO annulus via line CA-*01-SS-1".

\subsubsection{Tempered Water Cooling System}

- All TWC system instrumentation and control wiring to the MCS is per ANSI/NFPA 70, ANSI/IES RP1, and ANSI/IES RP7 to meet general service requirements.

- The TWC system interfaces with the CVDF electrical system are through hard wired connections with facility single-phase, $120 \mathrm{~V}$ (ac) electrical as needed. All wiring is per ANSI/NFPA 70.

- The CVDF instrument air system supplies the gas operated valves in the process bay with $90 \mathrm{lbf} / \mathrm{in}^{2}$ gauge instrument air via line IA-*01-SS-1/2".

- The CHW system supplies heat exchanger TWC-HX-7051 with $60 \mathrm{gal} / \mathrm{min}$ of $45^{\circ} \mathrm{F}$ chilled water via line CHW-SS-020-CT-21/2". 
- The TWC system supplies water cooler TW-CLR-3*10 with $20 \mathrm{gal} / \mathrm{min}$ of $50^{\circ} \mathrm{F}$ cooling water via line TWC-*01-SS-1 1/2".

\subsection{OPERABILITY}

\subsubsection{Tempered Water System}

$<$ List technical safety requirements when they are developed; this section is intended to specifically address and list the technical safety requirements for the system. $>$ TBD

\subsubsection{Tempered Water Cooling System}

$<$ List technical safety requirements when they are developed; this section is intended to specifically address and list the technical safety requirements for the system. > TBD

\subsection{TESTABILITY AND PERIODIC TESTING}

The TW system and the TWC system have sufficient testability designed into them to permit the periodic measurement and calibration of all setpoints and adjustments that affect the manner in which these systems perform. Periodic testing of their SSCs shall be dictated by the requirements of the individual components according to the respective manufacturer's recommended schedule and practice and as administered by controlled procedures for all safety class and safety significant SSCs.

\subsection{OPERATOR ACTIONS AND HUMAN FACTORS}

Operators direct the MCS when to initiate a sequence. The manual operator actions in the process sequences shall be field operator actions such as connecting quick-disconnect valves, operating manual block valves, and control room operator actions (e.g., acknowledging alarms or instructing the MCS to proceed with the next step). The coordination between the control room and the field operator for manual operations must be practiced.

\subsubsection{Tempered Water System}

The majority of TW system operation shall be automatically controlled by the MCS or SCIC system. Valve state changes, heater temperature control, gas supply pressure control, process status notification, and system alarm notification shall be performed by the MCS or SCIC system.

\subsubsection{Tempered Water Cooling System}

The majority of TWC system operation shall be automatically controlled by the MCS. Valve state changes, process status notification, and system alarm notification shall be performed by the MCS. 


\subsection{SPECIAL CONSIDERATIONS}

All aspects of the TW and TWC systems are in compliance with the Hanford Federal Facility Agreement and Consent Order (Ecology 1994), commonly referred to as the Tri-Party Agreement, and in compliance with applicable federal, state, and local laws and American Indian treaty rights.

\subsection{QUALITY ASSURANCE}

The TW system fabrication quality assurance/control program is based on the safety classification of the SSCs as detailed in the Safety Equipment List (HNF-SD-SNF-SEL-002) and application of a graded approach as described in the Project Hanford Quality Assurance Program Description (HNF-MP-599).

\subsection{REQUIRED CODES AND STANDARDS}

\subsubsection{Tempered Water System}

The TW system shall be constructed in strict accordance with the following material and fabrication standards.

- Code of Federal Regulations (CFR)

10 CFR 830.120 "Quality Assurance"

29 CFR 1910.120 "Occupational Safety and Health Standards"

- American Society of Mechanical Engineers (ASME)

B16.5 Pipe Flanges and Flanged Fittings (ANSI approved)

B16.10 Face to Face and End to End Dimensions of Valves

B16.11 Forged Steel Fittings, Socket-Welding and Threaded (ANSI approved)

B16.21 Nonmetallic Flat Gaskets for Pipe Flanges

B16.25 Buttwelding Ends

B16.34 Valves Flanged, Threaded, and Welding End

B16.39 Malleable Iron Threaded Pipe Unions Classes 150, 250, and 300 (ANSI approved)

B18.2.1 Square and Hex Bolts and Screws Inch Series Including Hex Cap Screws and Lag Screws (ANSI approved) 
B31.1 Power Piping Code (ANSI approved)

B31.3 Process Piping Code (ANSI approved)

Boiler and Pressure Vessel Code

Section II, "Material Specifications, Welding Rods,

Part C Electrodes, and Filler Metals"

Section VIII, "Rules for Construction of Pressure

Division I Vessels"

Section IX "Qualification Standard for Welding and Brazing Procedures, Welders, Brazers, and Welding and Brazing Operators"

NQA-1 Quality Assurance Requirements for Nuclear Facilities Applications

- American Society of Nondestructive Testing (ASNT)

SNT-TC-1A Recommended Practice

- American Welding Society (AWS)

D1.1 Structural Welding Code, Steel

- National Equipment Manufacturers Association (NEMA)

250 Enclosures for Electrical Equipment

- National Fire Protection Association (NFPA)

70 National Electrical Code

- Society of Automotive Engineers (SAE)

J429 Mechanical and Material Requirements for Externally Threaded Fasteners, Standard

\subsubsection{Tempered Water Cooling System} standards.

The TWC system is constructed in strict accordance with the following material and fabrication

- ANSI/ARI 550, Centrifugal or Rotary Screw Water Chilling Packages

- ANSI/ARI 590, Reciprocating Water Chilling Packages

- ANSI/ASME B31.9, General Services Piping Code 
- ASME Boiler and Pressure Vessel Code (ASME 1995), Section VIII

- ASME B16 Standards series, Fittings, Flanges and Valves 
SNF-3085 REV 0

This page intentionally left blank. 


\subsection{SYSTEM DESCRIPTION}

\subsection{GENERAL SUMMARY}

\subsubsection{Tempered Water System}

The TW system primarily comprises a water pump, cooler, heater, holding tank, piping valves, instrumentation, and controls mounted on the PES and process hood support stand. There is one TW system to service each of the four process bays.

Water pump TW-P-3*14 circulates the tempered water through the cask-MCO annulus. Heater TW-HTR-3*11 provides heater water to raise or maintain the temperature of the MCO for the drying stages. To cool the processed MCO to the storage temperature, cooler TW-CLR-3*10 uses cooling water from the TWC system to remove heat from the water. Holding tank TW-TK-3*12 ensures that the pump has a constant supply of water. The Cask seal ring assembly TW-SE- $1 * 13$ provides inteface connections and an annulus seal assembly at the top of the Cask-MCO.

\subsubsection{Tempered Water Cooling System}

The TWC system is a closed loop primarily comprising water pumps, heat exchanger, gas/liquid separator, and an expansion tank. Cooling water is brought to temperature in heat exchanger TWC-HX-7051 by chilled water from the CVDF CHW system. This cooling water is supplied to all TW systems at water cooler TW-CLR-3*10. Return water from TW-CLR-3*10 is received by gas/liquid separator TWC-SEP-7063 and expansion tank TWC-TK-7056. Discharge from TWC-TK-7056 is pumped back to TWC-HX-7051 by parallel water pumps TWC-P-7055 and TWC-P-7058.

\subsection{PIPING AND INSTRUMENTATION DIAGRAMS AND FLOW DIAGRAM}

Please refer to the TW and TWC system drawings listed in Table A-1 of Appendix A.

\subsection{SYSTEM ARRANGEMENT/CONFIGURATION}

\subsubsection{Tempered Water System}

Please refer to the piping and instrumentation diagrams and mechanical layout drawings, listed in Table A-1 of Appendix A, to gain a better understanding of the arrangement/configuration.

- Pipe TW-*03-SS-1" connects the outlet of TW-TK-3*12 to the inlet of tempered water pump TW-P-3*14.

- Valve TW-V-*035 blocks flow to the pump and is normally open. 
- PWC-*04-SS-1" connects TW-*03-SS-1" to PWC-*03-SS-1", to drain the TW system tank and system to the PWC system. Valve PWC-V-*051 blocks flow to the PWC system and is normally closed. A sample line branches from line PWC-*04-SS-1" and valve PWC-V-*033 blocks flow to the sample port and is normally closed.

- Pipe TW-*04-SS-11/2" connects the outlet of TW-P-3*14 to the inlet of water cooler TW-CLR-3*10.

- Pressure is monitored by pressure indicator TW-PIT-3*08 and associated control elements, TW-V-*032 is the instrument root valve for the pressure transmitter.

- Valve TW-V-*036 blocks flow to the cooler and is normally open.

- TW-CLR-3*10 is supplied with chilled water as the process dictates by TWC-*01-SS-11/2". Sequence-controlled block valve TWC-GOV-3*01 and associated control elements provide flow control of TWC-*01-SS-1 $1 \frac{1 / 2}{2}$ to the inlet into the cooler. Chilled water from TW-CLR-3*10 is recycled by TWC-*02-SS-1 1/2".

- Pipe TW-*05-SS-11/2" connects the outlet of TW-CLR-3*10 to the inlet of tempered water heater TW-HTR-3*11.

- Valve TW-V-*037 blocks flow from the cooler and is normally open.

- Pressure and flow are regulated via pipe TW-*06-SS-1" that branches off TW-*04-SS-11/2" and returns to TW-TK-3*12 through the pressure control valve, TW-SRV-3*11 (set at $25 \mathrm{lbf} / \mathrm{in}^{2}$ gauge), in parallel with the flow control valve, TW-FCV-3*18 (set at $6 \mathrm{gal} / \mathrm{min}$ ), on line TW-*07-SS-1".

- Temperature is monitored by temperature indicator TW-TIT-3*13 and associated control elements.

- At the PES, line TW-*01-SS-11/2" connects the outlet of TW-HTR-3*11 to the flexible pipe between the PES and the process hood.

- Sequence-controlled block valve TW-GOV-3*14 and associated control elements provide flow control of at the heater outlet.

- Temperature indicator TW-TIT-3*05 and associated control elements monitor temperature out of the heater and provide input for heater control.

- Flow element TW-FE-3*16 and associated control elements monitor flow at the heater outlet.

- At the process hood, TW-*01-SS-1 $1 \frac{1}{2}$ connects the flexible pipe between the PES and process hood to the flexible pipe between the process hood and cask-MCO assembly. TW-*01-SS-1 $1 \frac{1}{2}$ is designated safety class from before the safety class temperature switches to the cask-MCO assembly. 
- Safety class temperature switches TW-TSH-1*28 and TW-TSH-1*29 and associated control elements monitor the inlet temperature to the cask-MCO annulus.

- There are two anti-siphon bypass lines from TW-*01-SS-11/2" to TW-*02-SS-11/2". The flow through each line is controlled by safety-class flow control valves TWFCV $-1 * 22$ and TW-FCV-1*23. The bypass lines are designated as safety class.

- Safety class level gage TW-LG/LSL-1*25 and associated control elements monitor the water level within the cask-MCO annulus, there is also a drain petcock TW$\mathrm{V}-{ }^{*} 027$ that allows visual indication of water in the TW supply line during recovery actions.

- At the cask-MCO, a flexible pipe connects TW-*01-SS-11/2" at the process hood to the cask-MCO annulus at quick disconnect TW-QD-*018. The flexible pipe is designated as safety class.

- The tempered water flows through the annulus between the cask and MCO to the seal ring assembly, TW-SE-1*13, then to the flexible pipe connecting the cask-MCO annulus to TW-*02-SS-1 $1 \frac{12}{2}$ at the process hood. The cask-MCO assembly and flexible pipe is designated as safety class.

- A makeup supply line branches from the cask-MCO annulus outlet pipe. Valve TW-V-*021 blocks this inlet line and is normally closed.

- At the process hood, TW-*02-SS-11/2" connects the flexible pipe between the process hood and cask-MCO assembly to the flexible pipe between the process hood and the PES. TW-*02-SS-11/2" is designated as safety class from the cask-MCO assembly to after the anti-siphon bypasses.

- Safety class level gage TW-LG/LSL-1*24 and associated control elements monitor the water level within the cask-MCO annulus.

- There are two anti-siphon bypass lines from TW-*01-SS-11/2" to TW-*02-SS-11/2". The flow through each line is controlled by safety-class flow control valves TWFCV-1*22 and TW-FCV-1*23. The bypass lines are designated as safety class.

- At the PES, TW-*02-SS-11/2" connects the flexible pipe between the process hood and the PES to holding tank TW-TK-3*12.

- Pipe CA-*01-SS-1" supplies TW-*02-SS-11/2" with compressed air. Sequence controlled block valve CA-GOV-1*15 and associated control elements provide flow control of CA-*01-SS-1" to the TW system. CA-*01-SS-1" is controlled by pressure control valve CA-PCV-1*13 (set at $20 \mathrm{lbf} / \mathrm{in}^{2}$ gauge) and flow control valve CA-FI-1*18 (set at 5 standard $\mathrm{ft}^{3} / \mathrm{min}$ ). Compressed air is used to drain the cask-MCO annulus at the end of the CVD process cycle and to dry the annulus of residual water. 
- Sequence controlled block valve TW-GOV-1*14 and associated control elements provide flow control of TW-*02-SS- $1 \frac{1 / 2}{2}$.

- Temperature is monitored by temperature indicator TW-TIT- $3 * 12$ and associated control elements.

- Pipe PV-*02-SS-1" vents TW-TK-3*12 to the process vent system, Check valve PV-CKV-*060 blocks reverse flow into the expansion tank.

- Pipe DI-*02-SS-1" supplies TW-TK-3*12 with deionized water. Valve DI-V-*049 blocks the flow of DI-*02-SS-1" to the tank and is normally closed.

\subsubsection{Tempered Water Cooling System}

Please refer to the piping and instrumentation diagrams and mechanical layout drawings, listed in Table A-1 of Appendix A, to gain a better understanding of the arrangement/configuration.

- Pipe TWC-101-CT-2" connects the outlet of TWC-HX-7051 to the supply lines to the process bays, TW-*01-CT-11/2".

- Valve TWC-V-051 blocks flow to the process bay supply lines and is normally open.

- Valve TWC-V-064 balances flow to the process bay supply lines.

- Temperature transmitter TWC-TT-7054 and associated control elements monitor the outlet temperature of the heat exchanger and provide input for CHW flow control. TWC-TIC-7054 controls CHW-TV-7054 to adjust the flow rate on Line CHW-021-CT-21/2".

- Flow indicator TWC-FIT-7053 and associated control elements monitor flow at the heat exchanger outlet.

- Pressure indicator TWC-PI-7052 and associated control elements monitor the pressure at the heat exchanger outlet. Valve TWC-V-065 isolates the pressure indicator from the TWC system and is normally open.

- Pipe TWC-*01-CT-1 1/2" connects TWC-101-CT-2" in mechanical room 207 to pipe

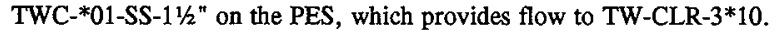

- Valve TWC-V-*51 blocks flow to each process bay and is normally open.

- Pipe TWC-*01-SS- $1 \frac{1 / 2}{2}$ connects TWC-*01-CT-1 1/2" to TW system water cooler TW-CLR-3*10 in the process bays.

- Sequence controlled block valve TWC-GOV-3*01 and associated control elements provide flow control of TWC-*01-SS-11/2" to the inlet of the cooler. 
- TW-CLR-3*10 is used to cool the tempered water as the process dictates.

- Pipe TWC-*02-SS-11/2" connects the cooler outlet in the process bays to TWC-*02-CT-1 1 $12 "$.

- Pipe TWC-*02-CT-11/2" connects line TWC-*02-SS-11/2" to TWC-001-CT-1" in mechanical room 207.

- Valve TWC-V-*52 blocks flow from the process bays to the TWC central system and is normally open.

- Pipe TWC-001-CT-1" interconnects between TWC-101-CT-2" and TWC-102-CT-2".

- Valve TWC-V-*51 blocks flow to TWC-*01-CT-11/2" and is normally open.

- Pressure control valve TWC-PCV-7055, set at $35 \mathrm{psig}$, regulates the flow between TWC-101-CT-2" and TWC-102-CT-2". If the TWC-101-CT-2" pressure exceeds the setpoint due to minimal flow requirements in the process bays, the valve will open to provide flow to the pumps. This maintains a minimum flow through the pumps. Valves TWC-V-052 and TWC-V-053 isolates TWC-001-CT-1".

- Valve TWC-V-*52 blocks flow from TWC-*02-CT-1 $1 \frac{12}{2}$ and is normally open.

- Pipe TWC-102-CT-2" connects TWC-001-CT-1" to the pumps TWC-P-7055 and TWC-P-7058.

- Strainer TWC-STR-054 provides a means of removing any particulates in the line to protect the pumps from damage. Valve TWC-V-054 isolates the strainer from the TWC system and is normally open.

- Safety relief valve TWC-SRV-7063 relieves pressure in the line to the floor if pressure exceeds $50 \mathrm{lbf} / \mathrm{in}^{2}$ gauge.

- Separator TWC-SEP-7063 vents gas from the expansion tank TWC-TK-7056 to the atmosphere.

- Expansion tank TWC-TK-7056 provides volume to absorb the expansion of water due to heating and to pressurize the system.

- Valve TWC-V-066 blocks flow from the hose connection for water fill and is normally closed. This stub-out is used to provide make-up water to the TWC system.

- Pressure indicator TWC-PI-7057 and associated control elements monitor pressure at the pump inlet. Valve TWC-V-057 isolates the pressure indicator from the TWC system and is normally open.

- Temperature transmitter TWC-TT-7062 and associated control elements monitor temperature at the pump inlet. 
- Valve TWC-V-055 block flow to primary pump TWC-P-7058 and is normally open. Valve TWC-V-056 throttles flow from primary pump TWC-P-7058.

- Valve TWC-V-059 block flow to secondary pump TWC-P-7055 and is normally closed.

- $\quad$ Primary pump TWC-P-7055 and secondary pump TWC-P-7058 recycle flow from the process bays through the heat exchanger and back to the process bays.

- Line TWC-101-CT-2" connects the pumps to heat exchanger TWC-HX-7051.

- Valve TWC-V-061 throttles flow from secondary pump TWC-P-7055 and is normally closed.

- Valve TWC-V-057 throttles flow from primary pump TWC-P-7058 and is normally open.

- Check valves TWC-CKV-057 and TWC-CKV-060 prevents backflow in the lines

- Pressure transmitter TWC-PT-7060 and associated control elements monitor the pressure at the pump outlet. Valve TWC-V-064 isolates the pressure indicator from the TWC system and is normally open.

- Pressure indicator TWC-PI-7061 and associated control elements monitor the pressure at the pump outlet. Valve TWC-V-062 isolates the pressure indicator from the TWC system and is normally open.

- Valve TWC-V-063 blocks flow to the heat exchanger and is normally open.

- Heat exchanger TWC-HX-7051 transfers heat from the TWC system to the CHW system.

\subsection{EXPLANATION OF HOW THE SYSTEM MEETS DESIGN REQUIREMENTS}

\subsubsection{Tempered Water System}

The following describes the safety performance requirements and explains how those requirements are met. The requirements, identified in italics, are excerpted from HNF-SD-SNF-DRD-002.

\subsubsection{HNF-SD-SNF-DRD-002, Section 5.4.3a.}

A. Process Requirement--The required flow rate of the TW system shall be a minimum of $56.8 \mathrm{~L} / \mathrm{min}(15 \mathrm{gal} / \mathrm{min})$ and shall have a design gauge pressure of $138 \mathrm{ka}\left(20 \mathrm{lb} / \mathrm{in}^{2}\right)$, with a maximum allowable gauge pressure of $172 \mathrm{ka}\left(25 \mathrm{lb} / \mathrm{in}^{2}\right)$ in the cask-MCO annular space. 
B. How the Requirement is Met--Pump TW-P-3*14 provides a $28 \mathrm{gal} / \mathrm{min}$ flow at a pressure of $62 \mathrm{ft}\left(27 \mathrm{lbf} / \mathrm{in}^{2}\right.$ gauge). TW-FCV-3*18 routes $6 \mathrm{gal} / \mathrm{min}$ of the outlet flow from TW-CLR-3*10 to TW-TK-3*12. TW-FCV-1*22 and TW-FCV-1*23 each route 1 $\mathrm{gal} / \mathrm{min}$ through a bypass to the cask-MCO annulus. Therefore, $20 \mathrm{gal} / \mathrm{min}$ is provided to the cask-MCO annulus. TW-SRV-3*11 routes flow from the cooler outlet when the pressure exceeds $25 \mathrm{lbf} / \mathrm{in}^{2}$ gauge. Therefore, the pressure of the tempered water cannot exceed $25 \mathrm{lbf} / \mathrm{in}^{2}$ gauge within the cask-MCO annulus.

\subsubsection{HNF-SD-SNF-DRD-002, Section 5.4.3b.}

A. Process Requirement--During vacuum drying, the TW system shall be able to heat the $M C O$ and maintain it at a temperature of approximately $50^{\circ} \mathrm{C}\left(122{ }^{\circ} \mathrm{F}\right)$ for a continuous period of not more than two days per drying operation to assist in the removal of residual water from the $M C O$.

B. How the Requirement is Met-Calculation CVD-10 (SNF-3001) shows that TW-HTR-3*11 provides enough energy to heat the $\mathrm{MCO}$ and its contents to $50^{\circ} \mathrm{C}$ within the required time period.

\subsubsection{HNF-SD-SNF-DRD-002, Section 5.4.3c.}

A. Process Requirement-The design temperature range is specified at $10^{\circ} \mathrm{C}$ to $50^{\circ} \mathrm{C}$ $\left(50{ }^{\circ} \mathrm{F}\right.$ to $\left.122^{\circ} \mathrm{F}\right)$.

B. How the Requirement is Met--Calculation CVD-10 (SNF-3001) shows that TW-HTR-3*11 provides enough energy to heat the $\mathrm{MCO}$ and its contents to $50^{\circ} \mathrm{C}$ within the required time period.

\subsubsection{HNF-SD-SNF-DRD-002, Section 5.4.3d.}

A. Process Requirement-After vacuum drying of the MCO, the TW system shall be required to cool the $\mathrm{MCO}$ and cask down to $15^{\circ} \mathrm{C}\left(59^{\circ} \mathrm{F}\right)$ at the water inlet, the required temperature for shipping.

B. How the Requirement is Met-Calculation CVD-10 (SNF-3001) shows that the TWC system cooling water stream $\left(20 \mathrm{gal} / \mathrm{min}\right.$ at $10^{\circ} \mathrm{C}$ ) through TW-CLR-3*10 can cool the $\mathrm{MCO}$ and its contents to $15^{\circ} \mathrm{C}$ within the required time period.

\subsubsection{HNF-SD-SNF-DRD-002, Section 5.4.3e.}

A. Process Requirement--The TW system shall be required to interface with the MCS to allow for computer control of $M C O$ heating and cooling during all stages of the drying operation.

B. How the Requirement is Met--The MCS controls the heating of the MCO by monitoring the TW-HTR-3*11 outlet temperature at TW-TIT- $3 * 05$ and using this input to adjust the TW-HTR-3*11 setpoint temperature at TW-TIC-3*05. The MCS monitors the water flow rate through the heater at TW-FI-3*16 to verify that the heater is receiving 
adequate flow. In addition, the MCS controls the heater outlet flow with sequence controlled block valve TW-GOV-3*14.

The MCS controls the cooling of the MCO by monitoring the TW-CLR-3*10 outlet temperature at TW-TI-3*13. The MCS controls the flow of chilled water to the cooler with sequence controlled block valve TWC-GOV-3*01. The MCS monitors the water flow rate through the cooler at TW-FI-3*16, to verify that the cooler is receiving adequate flow. In addition, the MCS controls the cooler outlet flow with sequence controlled block valve TW-GOV-3*14.

\subsubsection{HNF-SD-SNF-DRD-002, Section 5.4.3f.}

A. Process Requirement--Water heating shall be accomplished with an electric heater. Heater power shall be controlled with a silicon controlled rectifier. Water cooling shall be accomplished with a heat exchanger that transfers heat to a central CHW system. Deionized water shall be used for the make-up water.

TW system heating is provided by $100 \mathrm{~kW}$ electric heater TW-HTR-3*11. The heater is controlled by the MCS with TW-TIC-3*05. TW system cooling is provided by heat exchanger TW-CLR-3*10 supplied with $20 \mathrm{gal} / \mathrm{min}$ of cooling water at $10^{\circ} \mathrm{C}$. The TWC system is a centralized cooling water system that supplies the TW system with cooling water.

Make-up water for the TW system is deionized water and is supplied by line DI-*02-SS-1" at TW-TK- $3 * 12$. In addition, a stub-out at the cask-MCO annulus outlet on line TW-*02-SS-11/2" can be used to provide make-up water to the tempered water.

\subsubsection{HNF-SD-SNF-DRD-002, Section 5.4.3g.}

A. Process Requirement--Each cask will arrive with water in the annulus. Addition of the cask water to the system will require periodic release of water to maintain the system fill level. The TW system drain shall lead to the PWC system. The system shall have a method of draining the cask without draining the system. Either a pump or gas pressure may be used to move the water out of the cask.

B. How the Requirement is Met--While the TW system is providing tempered water to the cask-MCO annulus, water can be periodically released to the PWC through block valve PWC-V-*051.

During the cask-MCO annulus drain/dry step, TW-*01-SS-11/2" is disconnected from the cask-MCO assembly at quick disconnect TW-QD-*018, and quick disconnect PWC-QD-*020 is connected to the cask-MCO assembly to drain the tempered water from the cask-MCO annulus to the PWC system. To move the water from the cask-MCO annulus, sequence controlled block valve TWGOV-1*14 is closed to isolate the TW system from the cask-MCO assembly. The sequence controlled block valve CA-GOV-1*15 is opened to supply 5 standard $\mathrm{ft}^{3} / \mathrm{min}$ of compressed air at 20 $\mathrm{lbf} / \mathrm{in}^{2}$ gauge. The compressed air is used to displace the tempered water and dry the annulus in preparation for storage. 


\subsubsection{HNF-SD-SNF-DRD-002, Section 5.4.3h.}

A. Process Requirement--There shall be three process system connections to the cask. These shall be water and gas tight connect fittings that mate with fittings provided on the cask. There shall be a valve/pressure gauge arrangement in the upper connection to allow for measurement and bleed off of the cask pressure when the connection is made.

B. How the Requirement is Met--The cask lid has a quick disconnect process connection. Initially, line PV-*04-ST-1/4" is connected at quick disconnect PV-QD-*017. With block valve PV-V-*068 closed, PV-PI-1*32 indicates the pressure of the cask. With block valve PV-V-*068 opened, the gas in the cask is bled to the process vent system.

The cask-MCO annulus has two process connections. Line TW-*02-SS-1/2" is permanently connected to the outlet pipe from the cask-MCO annulus. The inlet pipe to the cask-MCO annulus has a quick disconnect process connection. Line TW-*01-SS-11/2" can be connected at quick disconnect TW-QD-*018 to supply the cask-MCO annulus with tempered water. Line PWC-*03-SS-1" can be connected at PWC-QD-*020 to drain the cask-MCO annulus of tempered water.

\subsubsection{HNF-SD-SNF-DRD-002, Section 5.4.3i.}

A. Process Requirement--The TW system shall be designed to maintain liquid in the cask annulus during design basis earthquakes, all credible accidents, and process upsets.

B. How the Requirement is Met--There are two safety class level switches in the TW system to maintain liquid in the cask-MCO annulus. The switches are set for $1 \mathrm{ft}$ above the minimum required water level in the annulus.

In the event of a break in the TW system piping due to an accident or design basis earthquake, the anti-siphon lines between TW-*01-SS-11/2" and TW-*02-SS-11/2" will prevent a siphon in the TW system from pulling water from the cask-MCO annulus. In the event of a break in the TW system piping between the level switch and the cask-MCO annulus that lowers the level of water in the annulus, make-up deionized water can be added to the system at the port of the annulus outlet.

\subsubsection{HNF-SD-SNF-DRD-002, Section 5.4.3j.}

A. Process Requirement--Water in the system may become slightly contaminated. There shall be provision for periodic sampling the water and flushing of the system with demineralized water.

B. How the Requirement is Met--The tempered water can be sampled at the sampling port that branches from PWC-*04-SS-1" near the TW-P-3*14 inlet. Deionized water can be added to the TW system for flushing at the TW-TK-3*12 by line DI-*02-SS-1". In addition, deionized water can be added to the TW system at the make-up port on the cask-MCO outlet piping. 


\subsubsection{HNF-SD-SNF-DRD-002, Section 5.4.3k.}

A. Process Requirement--The ring shall fit on the cask and be held in place with bolts using the bolt holes that are used for attaching the cask lid to the cask.

B. How the Requirement is Met-The seal ring is bolted to the top of the cask with three bolts using existing bolt holes in the cask as shown on Drawings H-1-83275, Cold Vacuum Drying Facility Seal Ring Assembly, and H-1-83276, Seal Ring Assembly Inflatable Seals.

\subsubsection{HINF-SD-SNF-DRD-002, Section 5.4.31.}

A. Process Requirement--The ring shall include a seal that retains water in the annulus while it is being circulated through the annulus with a maximum gauge pressure of $172 \mathrm{ka}(25 \mathrm{lbf} / \mathrm{in})^{2}$.

B. How the Requirement is Met--The seal ring is designed to provide primary confinement of the tempered water within the cask-MCO annulus up to a pressure of $25 \mathrm{lbf} / \mathrm{in}^{2}$ gauge as shown on Drawings $\mathrm{H}-1-83275$ and $\mathrm{H}-1-83276$.

\subsubsection{HNF-SD-SNF-DRD-002, Section 5.4.3m.}

A. Process Requirement--The center of the seal ring shall be open to allow process system connection access to the ports on the top of the MCO. The seal ring thickness shall be sized to resist the uplift load due to any credible water pressure from the circulating water within the cask annulus.

B. How the Requirement is Met--The seal ring is designed to provide primary confinement of the tempered water within the cask-MCO annulus up to a pressure of $25 \mathrm{lbf} / \mathrm{in}^{2}$ gauge as shown on Drawings H-1-83275 and H-1-83276.

\subsubsection{Tempered Water Cooling System}

\subsubsection{HNF-SD-SNF-DRD-002, Section 6.6.4.2a.}

A. Functional Performance Requirement--A central facility chilled water cooling system shall be designed to serve $T W$ system heat exchangers. The system concept shall include packaged chiller units, circulating pumps, associated piping, instrumentation, and controls.

B. How the Requirement is Met--The TWC system is a central system that provides cooling water to TW system coolers TW-CLR-3*10 of each process bay. The TWC system exchanges its heat with the CHW system, which uses a packaged chiller unit to provide chilled water. The TWC system comprises pumps TWC-P-7055 and TWC-P-7058, heat exchanger TWC-HX-7051, expansion tank TWC-TK-7056, and associated piping, instrumentation, and controls as represented on Drawing H-1-83768. 


\subsubsection{HNF-SD-SNF-DRD-002, Section 6.6.4.2c.}

A. Functional Performance Requirement--Expansion tanks shall be designed to the ASME Code, Section VIII, and shall include gauge glasses, drain valves, vent valves, and pressure relief valves.

B. The specified model for TWC-TK-7056 is designed to meet Boiler and Pressure Vessel Code (ASME 1995), Section VIII. Refer to Drawing H-1-82221, Cold Vacuum Drying Facility Mechanical Utilities Legend, Schedule, Notes.

\subsubsection{HNF-SD-SNF-DRD-002, Section 6.6.4.2d.}

A. Functional Performance Requirement-Make-up water shall be drawn from the potable water supply through a reduced pressure backflow assembly.

B. How the Requirement is Met--Potable water is supplied via line PW-001-CT-1" which includes a reduced pressure backflow preventer PW-RPBP-9022. Refer to Drawing H-1-82222, Cold Vacuum Drying Facility Mechanical Utilities Water and Compressed Gases P\&ID, sheet 1.

\subsubsection{HNF-SD-SNF-DRD-002, Section 6.6.4.2f.}

A. Functional Performance Requirement--All chilled water piping shall be designed and constructed in accordance with ANSI/ASME B31.3 or ANSI/ASME B31.9.

B. How the Requirement is Met--Specification Section 15510 states that chilled water piping installation shall conform to ANSI/ASME B31.9.

\subsubsection{HNF-SD-SNF-DRD-002, Section 6.6.4.2g.}

A. Functional Performance Requirement--Chilled water shall be provided from the facility chilled water cooling system.

B. How the Requirement is Met--Chilled water is provided to the TWC system heat exchanger TWC-HX-7051 by a central CHW system. The TWC system is a central system that provides cooling water to the TW system coolers in process bays TW-CLR-3*10.

\subsubsection{HNF-SD-SNF-DRD-002, Section 6.6.4.2h.}

A. Functional Performance Requirement-Chilled water shall not come in direct contact with process equipment surfaces (such as the MCO) that might be contaminated.

B. How the Requirement is Met-Chilled water in the CHW system removes heat from the $\mathrm{MCO}$ indirectly. The TW system interacts with the cask-MCO annulus. The TWC system removes heat from the TW system with TW-CLR-3*10, and the CHW system removes heat from the TWC system with TWC-HX-7051. 


\subsection{SYSTEM PARAMETERS AND SET POINTS}

\subsubsection{Tempered Water System}

The TW system has four main components with associated piping and instrumentation. The tag numbers, capabilities, and limitations of these components are listed below. The components are not subjected to conditions beyond the listed limitations.

5.5.1.1 Operating Limits. Equipment, components, and systems that comprise the TW system have been selected to perform specific functions. To maintain functionality and confidence in the operability of the system, the absolute operating limits in Table 5-1 must be respected. Violation of any of these limitations requires the replacement of the affected part before active service.

Table 5-1. Equipment Parameters.

\begin{tabular}{|l|l|l|l|}
\hline \multicolumn{1}{|c|}{ Tag number } & \multicolumn{1}{c|}{ Description } & \multicolumn{1}{|c|}{ Physical capabilities } & \multicolumn{1}{c|}{ Physical limitations } \\
\hline TW-CLR-3*10 & Water cooler & $230,000 \mathrm{Btu} / \mathrm{h}, 30 \mathrm{gal} / \mathrm{min}$ flowrate & $75 \mathrm{lbf} / \mathrm{in}^{2}$ gauge \\
\hline TW-HTR-3*11 & Water heater & $20 \mathrm{gal} / \mathrm{min}$ flowrate, $104 \mathrm{~kW}$ & $100 \mathrm{lbf} / \mathrm{in}^{2}$ gauge \\
\hline TW-TK-3*12 & Expansion tank & $47 \mathrm{gal}$. & $10 \mathrm{lbf} / \mathrm{in}^{2}$ gauge \\
\hline TW-P-3*14 & Water pump & $\begin{array}{l}1.5 \mathrm{hp}, 28 \mathrm{gal} / \mathrm{min} \text { at } 62 \mathrm{ft} \text { total } \\
\text { developed head }\end{array}$ & $\begin{array}{l}110^{\circ} \mathrm{C}, 6 \mathrm{gal} / \mathrm{min} \mathrm{minimum} \\
\text { flow }\end{array}$ \\
\hline
\end{tabular}

5.5.1.2 Precautions. System controls and presets preclude violation of system and component limitations under normal operations. Operations beyond normal conditions require inspection of the effected components to determine if operation limits have been exceeded. Items of special concern are noted in the operations manuals provided by the fabricator for the respective equipment and should be integrated into the normal operating procedures.

5.5.1.3 Recovery Procedures. Recovery from breakdown entails replacement and acceptance of the replacement part or component per operating procedures. Once replacements and acceptances are complete, a normal start-up procedure can be carried out to return to operations.

\subsubsection{Tempered Water Cooling System}

The TWC system has four main components with associated piping and instrumentation. The tag numbers, capabilities, and limitations of these components are listed below. The components are not subject to conditions beyond the listed limitations.

5.5.2.1 Operating Limits. Equipment, components, and systems that make up the TWC system have been selected to perform specific functions. To maintain functionality and confidence in the operability of the system, the absolute operating limits in Table 5-2 must be respected. Violation of any of these limitations requires the replacement of the affected part before active service.

Table 5-2. Components of the Tempered Water Cooling System. 
SNF-3085 REV 0

\begin{tabular}{|c|c|l|l|}
\hline Tag number & \multicolumn{1}{|c|}{ Description } & \multicolumn{1}{|c|}{ Physical capabilities } & \multicolumn{1}{|c|}{ Physical limitations } \\
\hline TWC-HX-7051 & Heat exchanger & $\begin{array}{l}230,000 \mathrm{Btu} / \mathrm{h}, 40 \mathrm{gal} / \mathrm{min} \text { flowrate, } \\
\text { plate type }\end{array}$ & \\
\hline TWC-TK-7056 & Expansion tank & $4.4 \mathrm{gal}$ & $150 \mathrm{lbf} / \mathrm{in}^{2} \mathrm{gauge}, 200^{\circ} \mathrm{F}$ \\
\hline TWC-P-7055 & Pump & $\begin{array}{l}1.5 \mathrm{hp}, 40 \mathrm{gal} / \mathrm{min} \text { at } 54 \mathrm{ft} \mathrm{total} \\
\text { developed head }\end{array}$ & $225^{\circ} \mathrm{F}$ \\
\hline TWC-P-7058 & Pump & $\begin{array}{l}1.5 \mathrm{hp}, 40 \mathrm{gal} / \mathrm{min} \text { at } 54 \mathrm{ft} \text { total } \\
\text { developed head }\end{array}$ & $225^{\circ} \mathrm{F}$ \\
\hline
\end{tabular}

5.5.2.2 Precautions. System controls and presets preclude violation of system and component limitations under normal operations. Operations beyond normal conditions require inspection of the affected components to determine if operation limits have been exceeded. Items of special concern are noted in the operations manuals provided by the fabricator for the respective equipment and should be integrated into the normal operating procedures.

5.5.2.3 Recovery Procedures. Recovery from breakdown entails replacement and acceptance of the replacement part or component per operating procedures. Once replacements and acceptances are complete, a normal startup procedure can be implemented to return to operations. 
SNF-3085 REV 0

This page intentionally left blank. 


\subsection{SYSTEM OPERATION}

The operating sequence of the TW system is described in HNF-2356, Spent Nuclear Fuel Project Cold Vacuum Drying Facility Operations Manual, and will not be repeated here. Off-normal scenarios are not discussed in this document. 
SNF-3085 REV 0

This page intentionally left blank. 


\subsection{SYSTEM SURVEILLANCE}

\subsection{MAINTENANCE}

The TW and TWC systems are designed to operate through the design life of the equipment (five years) without regularly scheduled facility shutdowns for maintenance. System maintenance activities are limited to maintenance due to failures. Additional maintenance activities and procedures may be scheduled if system surveillance, testing, or maintenance identifies additional requirements. All maintenance is performed under controlled procedures using approved (quality assurance-qualified) equipment and materials. Only spare parts meeting design criteria are procured and used. The equipment has been designed for efficient maintainability. The surveillance, testing, and maintenance of the system is achieved at minimum cost and level of support services per DOE Order 6430.1A, General Design Criteria, Section 1300-12.4.10.

\subsubsection{Maintenance Approach}

The short expected lifetime of the project, two years, and the high utilization of the TW system dictates a pragmatic approach to maintenance. The recommended maintenance schedules of the various components of the TW system need to be integrated and grouped into an unobtrusive maintenance program such that all scheduled maintenance takes place at or more frequently than the recommended schedule in the respective manuals.

\subsubsection{Corrective Maintenance and Preventive Maintenance}

- Maintenance features, including replacement of valves and piping connected to the primary barrier, are designed so that these activities are carried out under heating, ventilation, and air conditioning in-flow or isolation.

- Equipment and components have been located away from potentially contaminated areas wherever practical to reduce contact with contamination and to minimize situations requiring breach of containment.

- Modular design has been incorporated to permit easy change-out of systems requiring timely repair and/or special skills, and to reduce problems associated with equipment removal and repair.

- Commercial equipment, components, and parts are used wherever feasible to reduce procurement, maintenance, training, and inventory costs.

\subsubsection{Equipment Calibration}

- All equipment must be calibrated and recalibrated according to the respective manufacturer's recommended schedule and practice. Calibration and test connections have been provided to enable in-service testing and calibration when practical. 
- Equipment and instrumentation have local and remote readouts when available.

- Automatic on-line calibration has been specified when available.

- Modular replacement has been employed.

\subsection{NORMAL OPERATING INSPECTIONS}

Surveillance and in-service inspections need to be conducted per the manufacturer's recommendations for the respective components. Surveillance as dictated by the respective manuals are incorporated into standard operating procedures. Operators are expected to report and supervisors are expected to investigate any and all occurrences not regularly experienced during normal operations.

Accommodations have been made for both manual and electronic inspection of PES equipment. A computer port is available at the MCS for each PES to monitor and test the systems.

Hand-off-auto switches are available at selected points to allow for manual operation and inspection of various components.

The safety significant systems are under administrative control for all testing, surveillance, and maintenance, and are performed under controlled procedures. System operability is verified by surveillance of the system's component states (i.e., helium tank pressure, system alarms) before enabling the system for each MCO process cycle. The system requires additional surveillance, as necessary, to be operational beyond one normal processing cycle. 


\subsection{REFERENCES}

\subsection{INDUSTRY STANDARDS AND CODES}

10 CFR 830.120, "Quality Assurance Requirements," Code of Federal Regulations, as amended.

29 CFR 1910.120, "Occupational Safety and Health Standards," Code of Federal Regulations, as amended.

ANSI/ARI 550, 1992, Centrifugal or Rotary Screw Water Chilling Packages, Air Conditioning and Refrigeration Institute, Arlington, Virginia.

ANSI/ARI 590, 1992, Reciprocating Water Chilling Packages, Air Conditioning and Refrigeration Institute, Arlington, Virginia.

ANSI/ASME B16 Standards series, 1996, Fittings, Flanges and Valves, American Society of Mechanical Engineers, New York, New York.

ANSI/ASME B16.5, 1996, Pipe Flanges and Flanged Fittings, American Society of Mechanical Engineers, New York, New York.

ANSI/ASME B16.10, 1992, Face to Face and End to End Dimensions of Valves, American Society of Mechanical Engineers, New York, New York.

ANSI/ASME B16.11, 1996, Forged Steel Fittings, Socket-Welding and Threaded, American Society of Mechanical Engineers, New York, New York.

ANSI/ASME B16.21, 1992, Nonmetallic Flat Gaskets for Pipe Flanges, American Society of Mechanical Engineers, New York, New York.

ANSI/ASME B16.22, 1995, Wrought Copper and Copper Alloy Solder-Joint Pressure Fittings, American Society of Mechanical Engineers, New York, New York.

ANSI/ASME B16.25, 1997, Buttwelding Ends, American Society of Mechanical Engineers, New York, New York.

ANSI/ASME B16.34, 1996, Valves Flanged, Threaded, and Welding End, American Society of Mechanical Engineers, New York, New York.

ANSI/ASME B16.39, 1996, Malleable Iron Threaded Pipe Unions Classes 150, 250, and 300, American Society of Mechanical Engineers, New York, New York.

ANSI/ASME B18.2.1, 1992, Square and Hex Bolts and Screws Inch Series Including Hex Cap Screws and Lag Screws, American Society of Mechanical Engineers, New York, New York.

ANSI/ASME B31.1, 1996, Power Piping Code, American Society of Mechanical Engineers, New York, New York. 
ANSI/ASME B31.3, 1996, Process Piping Code, American Society of Mechanical Engineers, New York, New York.

ANSI/ASME B31.9, 1996, General Services Piping Code, American Society of Mechanical Engineers, New York, New York.

ANSI/ASME NQA-1, 1997, Quality Assurance Requirements for Nuclear Facility Applications, American Society of Mechanical Engineers, New York, New York.

ANSI/AWS-D1.1, 1996, Structural Welding Code-Steel, American Welding Society, Miami, Florida.

ANSI/IEEE-308, 1991, Standard Criteria for Class IE Power Systems for Nuclear Generating Stations, Institute of Electrical and Electronics Engineers, Piscataway, New Jersey.

ANSI/IEEE-338, 1987, Standard Criteria for the Periodic Surveillance Testing of Nuclear Power Generating Station Safety Systems, Institute of Electrical and Electronics Engineering, Piscataway, New Jersey.

ANSI/IEEE-379, 1994, Standard Application of the Single-Failure Criterion to Nuclear Power Generating Station Safety Systems, Institute of Electrical and Electronics Engineering, Piscataway, New Jersey.

ANSI/IEEE-384, 1992, Standard Criteria for Independence of Class IE Equipment and Circuits, Institute of Electrical and Electronics Engineering, Piscataway, New Jersey.

ANSI/IEEE-577, 1993, Standard Requirements for Reliability Analysis in the Design and Operation of Safety Systems for Nuclear Power Generating Stations, Institute of Electrical and Electronics Engineering, Piscataway, New Jersey.

ANSI/IEEE-603, 1991, Standard Criteria for Safety Systems for Nuclear Power Generating Stations, Institute of Electrical and Electronics Engineering, Piscataway, New Jersey.

ANSI/IES RP1, 1992, Practice for Office Lighting, Illuminating Engineering Society of North America, New York, New York.

ANSI/IES RP7, 1990, Practice for Industrial Lighting, Illuminating Engineering Society of North America, New York, New York.

ANSI/NEMA 250, 1991, Enclosures for Electrical Equipment (1000 Volts Maximum), National Electrical Manufacturers Association, Rosslyn, Virginia.

ANSI/NFPA 70, 1996, National Electrical Code, National Fire Protection Association, Quincy, Massachusetts.

ASME, 1995, Botler and Pressure Vessel Code, American Society of Mechanical Engineers, New York, New York.

Section II, "Material Specifications, Welding Rods, Part C Electrodes, and Filler Metals" 
Section VIII "Division I Rules for Construction of Pressure Vessels"

Section IX "Qualification Standard for Welding and Brazing Procedures, Welders, Brazers, and Welding and Brazing Operators"

ASME B73.1M, 1991, Specification for Horizontal End Section Centrifugal Pumps for Chemical Process, American Society of Mechanical Engineers, New York, New York.

ASME B73.2M, 1991, Specification for Horizontal In-Line Centrifugal Pumps for Chemical Process, American Society of Mechanical Engineers, New York, New York.

ASTM A36, 1993, Standard Specification for Structural Steel, American Society for Testing and Materials, West Conshohocken, Pennsylvania.

ASTM A105, 1996, Standard Specification for Forgings, Carbon Steel, for Piping Components, American Society for Testing and Materials, West Conshohocken, Pennsylvania.

ASTM A106, 1995, Standard Specification for Seamless Carbon Steel Pipe for High-Temperature Service, American Society for Testing and Materials, West Conshohocken, Pennsylvania.

ASTM A182, 1997, Standard Specification for Forged or Rolled Alloy-Steel Pipe Flanges, Forged Fittings, and Valves and Parts for High-Temperature Service, American Society for Testing and Materials, West Conshohocken, Pennsylvania.

ASTM A197, 1987(1992), Standard Specification for Cupola Malleable Iron, American Society for Testing and Materials, West Conshohocken, Pennsylvania.

ASTM A240, 1997, Standard Specification for Heat-Resisting Chromium and Chromium-Nickel Stainless Steel Plate, Sheet, and Strip for Pressure Vessels, American Society for Testing and Materials, West Conshohocken, Pennsylvania.

ASTM A269, 1996, Standard Specification for Seamless and Welded Austenitic Stainless Steel Tubing for General Service, American Society for Testing and Materials, West Conshohocken, Pennsylvania.

ASTM A276, 1997, Standard Specification for Stainless and Heat-Resisting Steel Bars and Shapes, American Society for Testing and Materials, West Conshohocken, Pennsylvania.

ASTM A307, 1993, Standard Specification for Carbon Steel Bolts and Studs, 60,000 psi Tensile Strength, American Society for Testing and Materials, West Conshohocken, Pennsylvania.

ASTM A312, 1995, Standard Specification for Seamless and Welded Austenitic Stainless Steel Pipes, American Society for Testing and Materials, West Conshohocken, Pennsylvania.

ASTM A354, 1997, Standard Specification for Quenched and Tempered Alloy Steel Bolts, Studs and other Externally Threaded Fasteners, American Society for Testing and Materials, West Conshohocken, Pennsylvania. 
ASTM A479, 1997, Standard Specification for Stainless and Heat-Resisting Steel Bars and Shapes for Use in Boilers and other Pressure Vessels, American Society for Testing and Materials, West Conshohocken, Pennsylvania.

ASTM A480, 1997, Standard Specification for General Requirements for Flat-Rolled Stainless Heat-Resisting Steel Plate, Sheet, and Strip, American Society for Testing and Materials, West Conshohocken, Pennsylvania.

ASTM A500, 1993, Grade B Specification for Cold Formed, Welded and Seamless Carbon Steel Structural Tubing in Rounds and Shapes, American Society for Testing and Materials, West Conshohocken, Pennsylvania.

ASTM A563A, 1993, Standard Specification for Carbon and Alloy Steel Nuts, American Society for Testing and Materials, West Conshohocken, Pennsylvania.

ASTM B88, 1996, Tube, Water, Seamless Copper, American Society for Testing and Materials, West Conshohocken, Pennsylvania.

ASTM E498, 1994, Leaks Using the Mass Spectrometer Leak Detector or Residual Gas Analyzer in the Tracer Probe Mode, Methods of Testing, American Society for Testing and Materials, West Conshohocken, Pennsylvania.

ASTM F593, 1995, Standard Specification for Stainless Steel Bolts, Hex Cap Screws, and Studs, American Society for Testing and Materials, West Conshohocken, Pennsylvania.

ASTM F594, 1991, Standard Specification for Stainless Steel Nuts, American Society for Testing and Materials, West Conshohocken, Pennsylvania.

SAE J429, 1983, Mechanical and Material Requirements for Externally Threaded Fasteners, Standard, Society of Automotive Engineers, Warrendale, Pennsylvania.

SNT-TC-1A, 1988, Recommended Practice, American Society of Nondestructive Testing, Columbus, Ohio.

\subsection{GOVERNMENT DOCUMENTS}

DOE Order 6430.1A, 1989, General Design Criteria, U.S. Department of Energy, Washington, D.C.

DOE-STD-1020-94, 1994, Natural Phenomena Hazards Design and Evaluation Criteria for Department of Energy Facilities, DOE Standard 1020-94, U.S. Department of Energy, Washington, D.C.

Ecology, 1994, Hanford Federal Facility Agreement and Consent Order, as amended, Washington State Department of Ecology, U.S. Environmental Protection Agency, and U.S. Department of Energy, Olympia, Washington. 


\subsection{SPENT NUCLEAR FUEL PROJECT DOCUMENTS}

HNF-2356, 1998, Spent Nuclear Fuel Project Cold Vacuum Drying Facility Operations Manual, Rev. 1, DE\&S Hanford, Incorporated, Richland, Washington.

HNF-SD-SNF-DRD-002, 1998, Cold Vacuum Drying Facility Design Requirements, Rev. 4, Fluor Daniel Hanford, Incorporated, Richland, Washington.

HNF-SD-SNF-SEL-002, 1998, Spent Nuclear Fuel Project Cold Vacuum Drying Facility Safety Equipment List, Rev. 5, Fluor Daniel Hanford, Incorporated, Richland Washington.

SNF-3001, 1998, CVDF Supporting Data and Calculation Database, Rev. 0, DE\&S Hanford, Incorporated, Richland, Washington.

\subsection{DRAWINGS}

H-1-82221, Cold Vacuum Drying Facility Mechanical Utilities Legend, Schedule, Notes, Rev. 0, Numatec Hanford Corporation, Richland, Washington.

H-1-82222, Cold Vacuum Drying Facility Mechanical Utilities Water and Compressed Gases P\&ID, Rev. 0, Numatec Hanford Corporation, Richland, Washington.

H-1-83275, Cold Vacuum Drying Facility Seal Ring Assembly, Rev. 0, Numatec Hanford Corporation, Richland, Washington.

H-1-83276, Seal Ring Assembly Inflatable Seals, Rev. 0, Numatec Hanford Corporation, Richland, Washington.

H-1-83766, Cold Vacuum Drying Facility Process System P\&ID, Rev. 4, Numatec Hanford Corporation, Richland, Washington.

H-1-83768, CVDF Chilled \& Tempered Cooling Water System P\&ID, Rev. 3, Numatec Hanford Corporation, Richland, Washington. 
SNF-3085 REV 0

This page intentionally left blank. 


\section{APPENDIX A}

\section{DRAWING AND SPECIFICATION LISTS AND SUPPORTING INFORMATION}

\section{DRAWING LIST}

TW and TWC system drawings are grouped under 13 drawing numbers. The primary drawing title of all drawings is Cold Vacuum Drying Facility. The secondary title, drawing numbers and sheet numbers for both systems are listed in Table A-1. Complete sets of drawings are located with the Spent Nuclear Fuel Project files for the Cold Vacuum Drying Facility project.

Table A-1. Tempered Water System and Tempered

Water Cooling System Drawings. (2 sheets)

\begin{tabular}{|c|c|c|c|}
\hline $\begin{array}{l}\text { Drawing } \\
\text { number }\end{array}$ & $\begin{array}{l}\text { Revision } \\
\text { number }\end{array}$ & Title & $\begin{array}{c}\text { Sheet } \\
\text { number }\end{array}$ \\
\hline \multicolumn{4}{|c|}{ General } \\
\hline H-1-82097 & 0 & Process Equipment Skid Drawing List \& Vicinity Map & 1 \\
\hline \multicolumn{4}{|c|}{ Structural } \\
\hline $\mathrm{H}-1-82352$ & 0 & Structural Skids - VPS and MCTC & 1 \\
\hline H-1-82353 & 0 & Structural Skids - VPS and MCTC Details & 1 \\
\hline \multicolumn{4}{|c|}{ Mechanical } \\
\hline H-1-82362 & 0 & Process Equipment Skid Recirc. Tank TW-TK-3*12 & 1 \\
\hline \multicolumn{4}{|c|}{ Mechanical } \\
\hline $\mathrm{H}-1-83275$ & $\mathbf{0}$ & Seal Ring Assembly & 1 \\
\hline H-1-83275 & $\mathbf{0}$ & Seal Ring Assembly & 2 \\
\hline H-1-83275 & 0 & Seal Ring Assembly & 3 \\
\hline H-1-83276 & $\mathbf{0}$ & Seal Ring Assembly Inflatable Seals & 1 \\
\hline \multicolumn{4}{|c|}{ Piping and instrumentation diagrams } \\
\hline H-1-82160 & $\mathbf{0}$ & P\&ID Legend & 1 \\
\hline H-1-82163 & 0 & Process Equipment Skid P\&ID MCO/Temp. Water Sys. & 1 \\
\hline H-1-82221 & 0 & Mechanical Utilities Legend, Schedule, Notes & 1 \\
\hline $\mathbf{H}-1-82222$ & 0 & Mechanical Utilities Wtr. \& Compressed Gases P\&ID & 1 \\
\hline H- $1-83766$ & 4 & Process System P\&ID & 1 \\
\hline H-1-83766 & 4 & Process System P\&ID & 2 \\
\hline H-1-83768 & 3 & Chilled \& Tempered Cooling Water System P\&ID & 1 \\
\hline \multicolumn{4}{|c|}{ Piping } \\
\hline
\end{tabular}


Table A-1. Tempered Water System and Tempered

Water Cooling System Drawings. (2 sheets)

\begin{tabular}{|c|c|l|c|}
\hline $\begin{array}{c}\text { Drawing } \\
\text { number }\end{array}$ & $\begin{array}{c}\text { Revision } \\
\text { number }\end{array}$ & \multicolumn{1}{|c|}{ Title } & $\begin{array}{c}\text { Sheet } \\
\text { number }\end{array}$ \\
\hline H-1-82351 & 0 & Process Equipment Skid Piping General Arrangement & 1 \\
\hline H-1-82351 & 0 & Process Equipment Skid Piping Plan and Elevation & 2 \\
\hline H-1-82351 & 0 & Process Equipment Skid Piping Section and Details & 5 \\
\hline & & & Instrumentation \\
\hline H-1-82302 & N & Process Equipment Skid Junction Box Assembly & 1 \\
\hline H-1-82302 & N & Process Equipment Skid Connection Diagram & 2 \\
\hline H-1-82302 & N & Process Equipment Skid Connection Diagram & 3 \\
\hline
\end{tabular}

\section{SPECIFICATION LIST}

The TW system is procured as part of the process equipment skid and process hood procurement packages. Two specifications make up the TW system (see Table A-2).

Table A-2. Tempered Water System Specifications.

\begin{tabular}{|c|l|}
\hline Specification number & \multicolumn{1}{|c|}{ Title } \\
\hline W-441-P1 & $\begin{array}{l}\text { Procurement Specification for the Fabrication, Acceptance Testing, and Shipment of the } \\
\text { Cold Vacuum Drying Facility Process Skid and System Equipment }\end{array}$ \\
\hline W-441-P4 & $\begin{array}{l}\text { Procurement Specification for the Fabrication, Acceptance Testing, and Shipment of the } \\
\text { Cold Vacuum Drying Facility Process Hood and System Equipment }\end{array}$ \\
\hline
\end{tabular}

The tempered water cooling system is procured as part of the Cold Vacuum Drying Facility construction package. Three specifications make up the tempered water cooling system (see Table A-3).

Table A-3. Tempered Water Cooling System Specifications.

\begin{tabular}{|c|l|}
\hline Specification number & \\
\hline 15010 & General Mechanical \\
\hline 15510 & Chilled Water Piping \\
\hline 15540 & HVAC Pumps \\
\hline
\end{tabular}




\section{INSTRUMENT AND VALVE LISTS}

The controlled valve, instrumentation, and control tag numbers of the contaminated water sampling and analysis system are listed in HNF-SD-SNF-SEL-002, Rev. 5, 1998, Spent Nuclear Fuel Project Cold Vacutum Drying Facility Safety Equipment List. 